\title{
Simultaneous normal faulting and extensional flexuring during rifting: an example from the southernmost Upper Rhine Graben
}

\begin{abstract}
The southern end of the Upper Rhine Graben (URG) is formed by a major continental transfer zone, which was localised by the reactivation of ENE-oriented basement faults of Late Palaeozoic origin. A combination of subcrop data (derived from exploration wells and reflection seismic lines) and palaeostress analysis provided new constraints on the timing and kinematics of interacting basement faults. Rifting in the southern URG began in the Upper Priabonian under regional WNW-ESE-directed extension, oriented roughly perpendicular to the graben axis. In the study area, this led to the formation of NNE-trending half-grabens. Simultaneously, ENE-trending basement faults, situated in the area of the future Rhine-Bresse Transfer Zone (RBTZ), were reactivated in a sinistrally transtensive mode. In the sedimentary cover the strike-slip component was accommodated by the development of en-échelon aligned extensional flexures. Flexuring and interference between the differently oriented basement faults imposed additional, but locally confined extension in the sedimentary cover, which deviated by as much as $90^{\circ}$ from the regional WNW-ESE extension. The interference of regional and local stresses led to a regime approaching radial extension at the intersection between the URG and RBTZ.
\end{abstract}

Keywords Extension - Fault reactivation · Upper Rhine Graben · Rhine-Bresse Transfer Zone · Palaeostress analysis

K. Ustaszewski $(\bowtie) \cdot$ M. E. Schumacher $\cdot$ S. M. Schmid EUCOR-URGENT Group, Department of Geosciences, University Basel, Bernoullistrasse 32, 4056 Basel, Switzerland E-mail: Kamil.Ustaszewski@unibas.ch

Tel.: + 41-61-2670909

Fax: + 41-61-2673613

\section{Introduction}

Objectives and previous work

The N- to NE-trending Bresse- and Upper Rhine Graben (URG) structures (top right inset in Fig.1) form the central segments of the European Cenozoic rift system. Their simultaneous opening was kinematically linked by activity along the Rhine-Bresse Transfer Zone (RBTZ), which formed along pre-existing, ENE- to NE-oriented crustal discontinuities, inherited from the Variscan orogeny and subsequent (Late Carboniferous to Permian) post-orogenic transtension (Laubscher 1986; Ziegler 1992; Schumacher 2002). Transfer of rifting from the Bresse Graben to the URG implies sinistral motions along the RBTZ (Laubscher 1972; Laubscher 1973; Illies 1981; Ziegler 1992). The analysis of striated faults in the Mesozoic to Cenozoic cover revealed that Eo-/Oligocene extension across the Bresse and URG, as well as in the RBTZ, occurred under a WNW-ESE oriented minimum principal stress $\sigma 3$, perpendicular to the graben axis (Bergerat 1987; Larroque and Laurent 1988; Lacombe et al. 1993). Due to the inaccessibility of the basement in the RBTZ, the kinematics of basement faults in this zone were inferred indirectly, for instance from comparison with analogue models of oblique rift systems. Extension applied obliquely to the external boundaries of models built above two diverging basal sheets, produces steeply dipping en-échelon faults (Elmohandes 1981; Tron and Brun 1991; McClay et al. 2002). Such models imply transtensional reactivation of the basal discontinuity and yield fault patterns comparable to those encountered in the RBTZ. Consequently, it was argued that the fault pattern in the RBTZ formed in response to regional-scale sinistral transtensional reactivation of ENEto NE-oriented basement faults trending obliquely to the extension direction (Lacombe et al. 1993).

The aim of this study is to provide further constraints on the kinematics, the stress field and the interaction of differently oriented faults in response to Palaeogene 
Fig. 1 Geologic-tectonic map of the southernmost URG and adjacent areas. Al Allschwil Fault, DM Dannemarie Basin, $F$ Florimont flexure, $F e$ Ferrette Fault, $I F$ Illfurth Fault, $R$ Réchésy flexure. Fold axes are only shown along the Jura front. Neogene thrusts are not shown. Top right: $B G$ Bresse Graben, RBTZ Rhine-Bresse transfer zone, $U R G$ Upper Rhine Graben
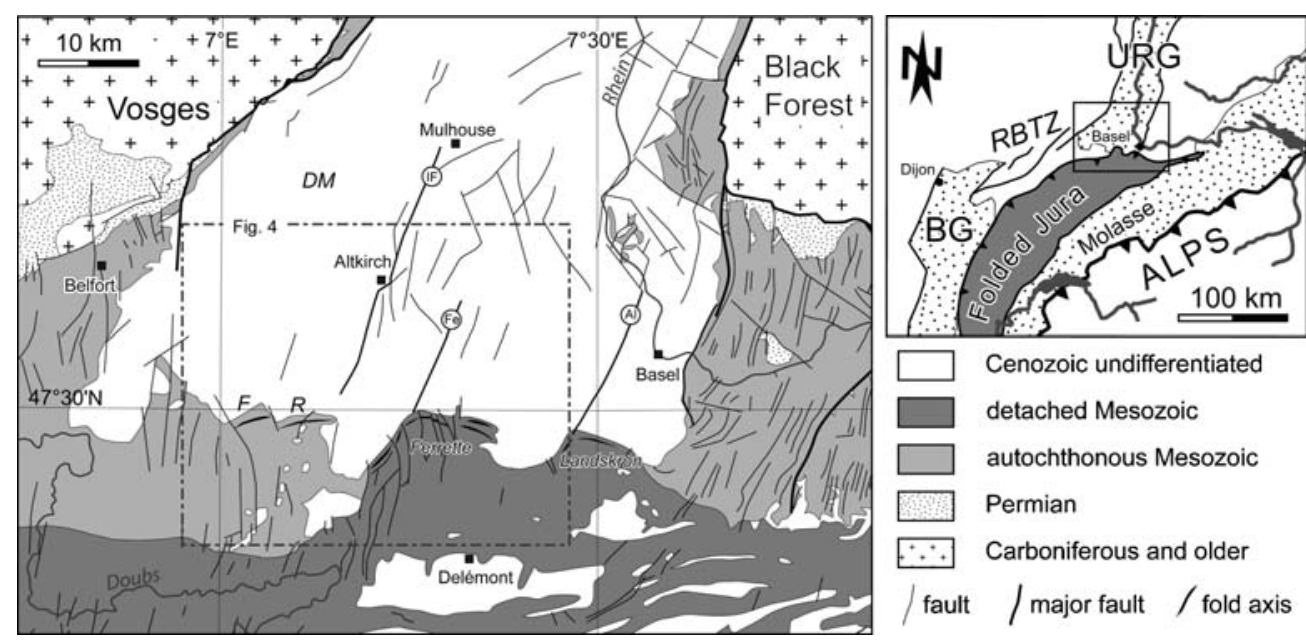

rifting. Subsurface information, derived from industry type reflection seismic lines and well logs, was compiled into new subcrop maps and combined with kinematic analyses from faults collected in the sedimentary cover. This led to the development of a new kinematic model for the Palaeogene rifting episode. Our model emphasises the importance of pre-existing faults and illustrates the simultaneous interaction between differently oriented basement faults at the transition from the URG to RBTZ.

\section{Geological setting}

The area investigated in this study is located at the junction between the southernmost URG and the RBTZ (top right inset in Fig. 1). The southern part of the Tertiary fill of the URG is juxtaposed against autochthonous and detached Mesozoic sediments (Fig. 1). These sediments overlie a Palaeozoic basement (comprising clastic and volcanoclastic lithologies of Devonian to Upper Permian age), outcropping in the Vosges and Black Forest massifs. The Mesozoic cover ranges in age from Lower Triassic to Upper Jurassic. In northern Switzerland, the autochthonous Mesozoic cover is usually referred to as Tabular Jura due to the sub-horizontal orientation of the sediments of predominantly Jurassic age. The Mesozoic of the Folded Jura has been detached along Mid- and Upper Triassic evaporites during Upper Miocene to Lower Pliocene thin-skinned folding and thrusting. Cenozoic sediments (Eocene to Quaternary) not only constitute the fill of the URG, but are also preserved in basins and grabens within the Tabular Jura, as well as in intra-montane synclines within the Folded Jura. The largest of these synclines is the lozenge-shaped Delémont Basin (Fig. 1). The eastern and western borders of the URG are characterised by discrete faults. The Dannemarie Basin (DM in Fig. 1) is the area of largest rift-related subsidence in the southernmost URG and is bounded in the east by the Illfurth fault. Additional important faults located within the graben further to the east are the Ferrette and the Allschwil faults.

The overall E-W-trending southern graben border, on the other hand, is formed by extensional flexures (monoclines) and/or compressional anticlines. The flexures formed during Eo-/Oligocene rifting. They were partly reactivated in post-Oligocene times under compression in conjunction with Jura folding (Ferrette anticlines and Landskron anticlines). Of particular interest to this study is the en-échelon alignment of two gentle anticlines further to the west: the so-called Florimont and Réchésy (labelled " $F$ " and " $R$ " in Fig. 1, respectively), which formed by reactivation of Eo-/Oligocene extensional flexures (Giamboni et al. 2004). The E-W-trending southern border of the URG is interrupted by three conspicuous embayments, containing Tertiary sediments, which encroach southward on the Jura domain (Fig. 1). Numerous N- to NNE-, ENEand subordinately NW-striking normal faults dissect the Mesozoic series of the Tabular Jura and the Tertiary fill of the URG.

\section{Palaeogene rifting}

Rift-related subsidence of the southern URG began in Late Eocene times and persisted until the Late Oligocene to Early Miocene (Pflug 1982). During an initial phase of rifting, half-grabens and gentle flexures formed in conjunction with W-dipping NNE-SSW-striking normal faults. Flexures formed also along the southern border of the URG (Liniger 1970a; Laubscher 1982; Fig. 1). While partly bituminous marls and evaporites accumulated in the Mulhouse and DM (Salt Formation; Doebl 1970; Sissingh 1998), fresh- to brackish-water and even terrestric sedimentation prevailed on horsts in the southernmost graben part ("Melania limestone" Member of the Lower Salt Formation, "Haustein" Member of the Upper Salt Formation; Sissingh 1998). Coarse conglomerates formed along the graben margins in response to increasing uplift and erosion of the rift flanks 
(P. Duringer, unpublished results). This style of sedimentation persisted until the Lower Rupelian (P. Duringer, unpublished results; Picot 2002).

Full marine conditions were not established before the Upper Rupelian transgression of the "Foraminifera Marl", "Fischschiefer", and "Meletta beds" (Fischer 1965a, 1969; P. Duringer, unpublished results). These sediments grade southward into thin-bedded, compact calcarenites, the so-called "Meeressand", indicating coastal facies (Fischer 1965a). The spatial distribution of the Upper Rupelian sediments includes domains within the Tabular and Folded Jura as far south as the Delémont Basin (Fig. 1). During the Chattian, sedimentation once again became brackish ("Cyrena Marls") and eventually fluvio-lacustrine ("Alsacian Molasse"; Fischer 1965a, 1969). Upper Chattian to lowermost Aquitanian freshwater limestones formed in a period when connections to the marine realm were interrupted (Sissingh 1998).

During the Burdigalian, rift-related subsidence of the southern URG stopped and its sedimentary fill was subjected to erosion (Laubscher 1992; Dèzes et al. 2004). This erosion was related to the uplift of the VosgesBlack Forest arch, which developed either in response to the arrival of the northward migrating Alpine forebulge (Laubscher 1987, 1992) or in response to lithospheric folding (Ziegler et al. 2004). The uplift was associated with a change in the regional stress pattern from vertical $\sigma 1$ and WNW-ESE trending $\sigma 3$ to horizontal and NNW-SSE-trending $\sigma 1$ (Larroque and Laurent 1988). Marine Burdigalian sediments, unconformably overlying Chattian to lowermost Aquitanian freshwater limestones in the Delémont Basin, mark the transgression of the Upper Marine Molasse (OMM; Koch 1923). Hence, this transgression is by no means related to renewed extension in the URG, but rather to subsidence of the Molasse Basin in front of the advancing Alpine orogen (Sissingh 1998). This is clearly evidenced in the Tabular Jura east of Basel, where Eo-/Oligocene normal faults are unconformably overlain and sealed by the trans- gression of the OMM (Buxtorf 1901; Bitterli-Brunner 1988).

\section{Control of Late Palaeozoic structures on Palaeogene rifting}

The distribution of partly fault-controlled Permo-Carboniferous troughs in northern Switzerland and adjacent France and Germany is given in Fig. 2. The thickness of Carboniferous to Permian sediments (Boigk and Schöneich 1970, 1974) is constrained by outcrops (Lutz 1964) and by 22 exploration wells, some of which bottomed in the basement (Schmassmann and Bayramgil 1945; Diebold 1989; Häring 2003). The subsurface faults shown in Fig. 2 were adopted from French subcrop maps (Debrand-Passard and Courbouleix 1984), reports of the Swiss National Cooperative for Storage of Nuclear Waste (Laubscher 1986; Sprecher and Müller 1986; Diebold 1989; Diebold and Naef 1990) and results of the Swiss National Research Program NRP20 (Diebold and Noack 1997; Laubscher and Noack 1997; Pfiffner et al. 1997). Isopachs and fault traces were locally modified according to our own observations.

The salient feature of Fig. 2 is the occurrence of a system of generally ENE-trending, narrow and elongated, predominantly fault-bounded troughs beneath the northern Folded Jura Mountains and their foreland. This $10-15 \mathrm{~km}$ wide trough system extends from Lake Constance in the east into the central part of Fig. 2 ("Constance-Frick trough") and is filled with up to $1,000 \mathrm{~m}$ of Permo-Carboniferous clastic sediments. It follows the structural grain of the Variscan belt and developed in response to post-Variscan transtension (Ziegler 1990). Differential subsidence in these intramontane troughs ended in Mid-Permian times, giving way to regional thermal subsidence of the area (Ziegler et al. 1990, 2004).

The western continuation of the Constance-Frick trough into the study area coincides with the southern
Fig. 2 Late Palaeozoic troughs and highs in the southernmost Upper Rhine Graben and adjacent areas. $R F$ Rhenish Fault, $W F$ Wehratal Fault. For orientation, the outline of the URG is shown by a black dashed line. Bottom right inset: overview map of present-day situation

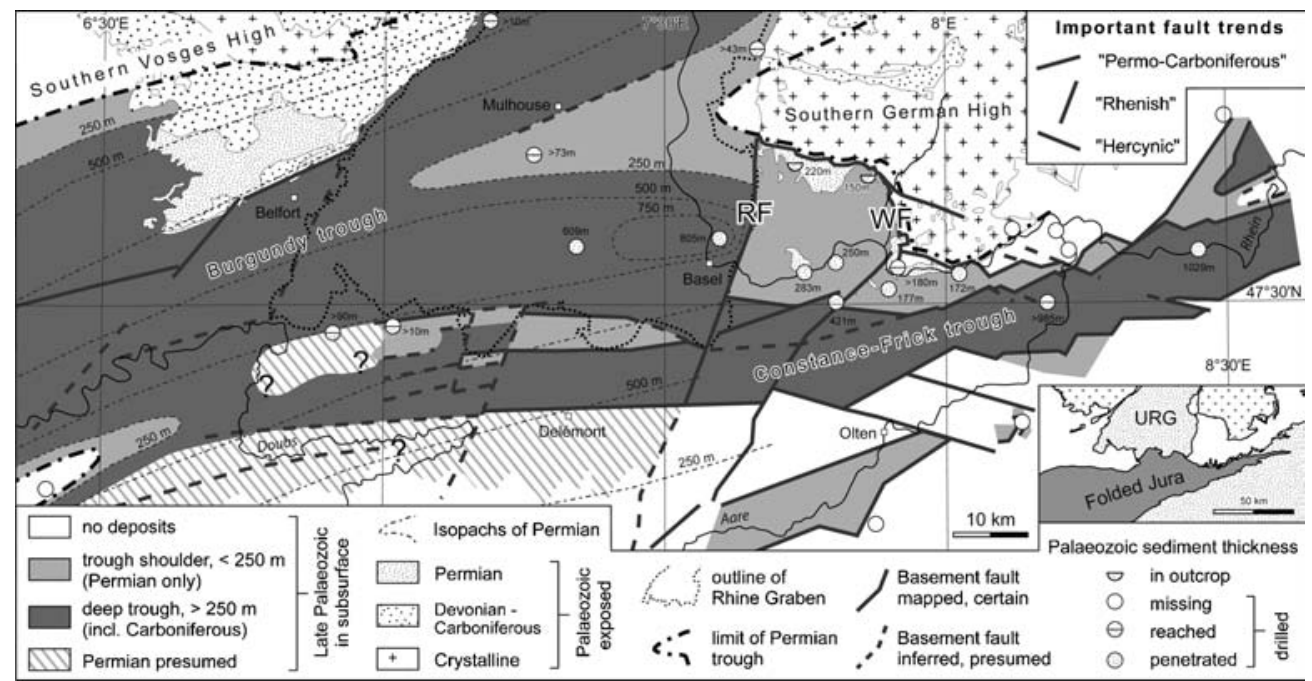


termination of the URG and the location of the RBTZ. Due to the scarcity of well data in this area, the structure of this part of the trough is mainly constrained by reflection seismic data. In the southern Vosges further to the west, the thickness of Permo-Carboniferous sediments is constrained by outcrops. A distinction was made between "deep troughs" (thickness of Permian sediments $>250 \mathrm{~m})$ and "trough shoulders" $(<250 \mathrm{~m}$ Permian). Despite limited well and seismic control it is obvious that the Constance-Frick trough links up with the southern branch of the Burgundy trough. Nevertheless, a narrow horst apparently separates the Burgundy and Constance-Frick trough in the area of the southernmost URG (Fig. 2). A large part of this Late Palaeozoic trough system terminates to the east at the NE- to N-trending Wehratal Fault ("WF" in Fig. 2). While Permian clastics are present below the Triassic Buntsandstein west of the WF, they are missing east of this fault, where Buntsandstein rests directly on the granitic basement of the Black Forest. This suggests Late Palaeozoic differential vertical motions across this fault.

The Rhenish Fault (RF in Fig. 2), further to the west, was also active during the Late Palaeozoic and has a trend similar to the WF. Its location coincides with the eastern border fault of the southernmost URG. It also separates areas of contrasting thickness of Permo-Carboniferous sediments (i.e. $>800$ and $<300 \mathrm{~m}$ west and east of the RF, respectively, see Fig. 2). The spatial coincidence of the RF with the south-eastern border fault of the future URG illustrates that parts of it were localised along pre-existing Late Palaeozoic faults. Geomagnetic studies revealed other such NNE-trending Late Palaeozoic faults in the subsurface of the URG and in the Vosges and Black Forest, (Edel and Fluck 1989). In the southern Black Forest Upper Carboniferous to Permian lamprophyres and aplitic dikes are subparallel to the URG (Werner and Franzke 2001 and references therein). Evidence for Mesozoic reactivation of Late Palaeozoic faults has recently been provided by stratigraphic investigations in the northern Swiss Jura Mountains, where faciesboundaries between basins and highs tend to be aligned with the RF and other features of the Permo-Carboniferous trough (R. Allenbach, unpublished results; Allenbach 2002; Wetzel et al. 2003).

In summary, the location of the southern end of the URG and its connection with the Bresse Graben via the RBTZ appears to be controlled by two pre-existing fault sets. A first set consists of ENE-trending faults, referred to as the "Permo-Carboniferous set", which, for example, delimits the small Palaeozoic high located between the western part of the Constance-Frick trough and the easternmost main part of the Burgundy trough. The second, "Rhenish" set refers to the NNE-trending faults. In the following, we apply these terms also to fault sets that were active during Tertiary rifting, since localisation of the URG and the RBTZ was controlled by these Late Palaeozoic fault systems.

\section{Subsurface data}

Structure of the base of the Mesozoic surface

In order to define the structural configuration of the base of the Mesozoic surface (or base-Mesozoic surface for short), a contour map of this surface, including the fault trends dissecting it, was compiled. A network of industrytype reflection-seismic lines was analysed, covering an approximately $30 \times 20 \mathrm{~km}$ wide area straddling the southernmost URG and the southward adjacent Tabular and Folded Jura (bottom centre inset in Fig. 3). Moreover, six exploration wells (Schmidt et al. 1924; BRGM, unpublished) allowed the correlation of seismic reflectors with drilled lithologies (Fig. 3). Four of these wells penetrated the Tertiary fill and bottomed in Mesozoic sediments, whereas the other two reached Palaeozoic siliciclastics and/or the crystalline basement. The correlated logs of the penetrated Tertiary and Mesozoic sedimentary succession together with the observed seismic interval velocities of three of the wells are shown in Fig. 3. The base of the Mesozoic succession is often marked by an angular unconformity between Permian clastic series and the overlying basal Triassic Buntsandstein. The Mesozoic series exhibit a remarkably constant thickness, as evident from well logs and strictly parallel seismic reflections. Once the base of the Mesozoic had been identified (by finding the angular unconformity), it was extrapolated throughout the remaining part of a seismic section and subsequently onto intersecting lines. The top Mesozoicunconformity is often marked by onlapping Tertiary reflections. Furthermore, this unconformity gives rise to a discrete reflector due to the high acoustic impedance contrasts between the uppermost Mesozoic and lowermost Tertiary layers.

After identification of the base of the Mesozoic on the seismic lines, its depth (in seconds two-way-travel time, s TWT) was plotted on a map and contoured manually. The resulting map (seismic reference datum at $500 \mathrm{~m}$ above sea level, Fig. 4) shows that the depth of the baseMesozoic surface ranges from $0.55 \mathrm{~s}$ TWT to $1.3 \mathrm{~s}$ TWT in the mapped area. This corresponds to a depth range of between about $650 \mathrm{~m}$ and $1,350 \mathrm{~m}$ below sea level, as calculated from seismic velocities obtained from the exploration wells Buix1 (base-Mesozoic at $646 \mathrm{~m}$ below sea level) and Knol (base-Mesozoic at 1,021 m below sea level), both of which had penetrated the base of the Mesozoic succession. The shallowest elevations of the base-Mesozoic surface are found beneath the exposed Mesozoic in the south, where this surface reveals only moderate relief. Substantial relief is observed in the area of the URG, where the base of the Mesozoic reaches its greatest depth in the DM (Fig. 4).

Two sets of differently oriented normal faults dissect the base-Mesozoic surface: the Rhenish set, which trends NNE $\left(20^{\circ} \mathrm{N}-30^{\circ} \mathrm{N}\right)$, parallel to the URG, and the Permo-Carboniferous set, which trends ENE $\left(70^{\circ} \mathrm{N}-80^{\circ} \mathrm{N}\right)$, parallel to the Late Palaeozoic trough system (compare 
Fig. 3 Logs of three exploration wells in the study area, showing the Mesozoic to Palaeogene stratigraphy, plotted versus two-way travel times in seconds (s TWT). The resulting interval velocities are in metres per second. $B M$ base Mesozoic, $M$ top Muschelkalk, $K$ top Keuper, $L$ top Lias, $O$ top Aalenian, $D$ top Dogger, $A$ top Malm. The approximately $20 \mathrm{~m}$ thick Upper Rupelian interval (wells Sund201 and Sund203) corresponds to the most important reflector (" $\mathrm{R}$ ") in the syn-rift sediments. Bottom centre inset: location of the investigated seismic lines and six explorations wells used. Numbers on map margin refer to Swiss National coordinates

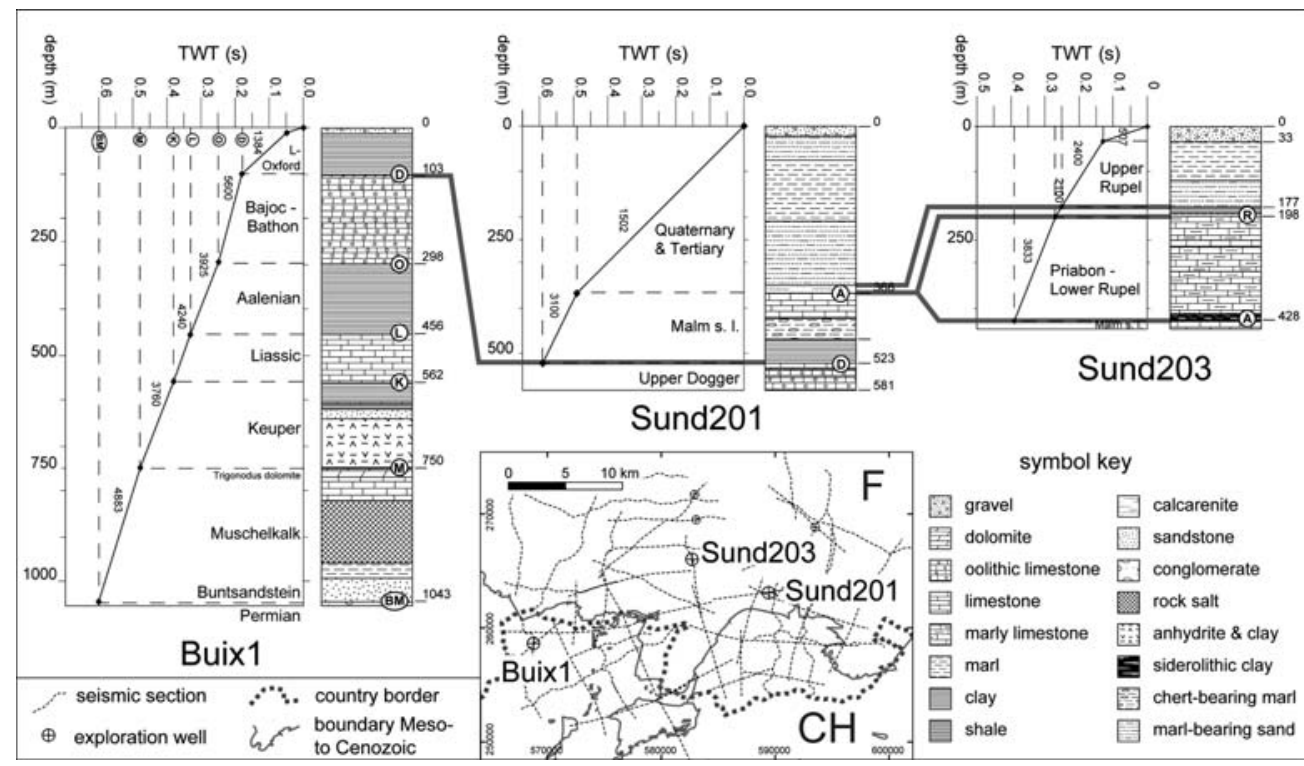

with Fig. 2). Fault heave is only significant along two of the mapped faults. The largest fault identified (Ferretta Fault, Fig. 4) can be traced for $25 \mathrm{~km}$ in a NNE-direction. It probably extends further south into the Folded Jura Mountains, as deduced from the parallelism between the fault trend and the strike of the western part of the conspicuously northward-protruding Neogene Ferrette anticline, as well as from numerous minor faults in the detached Mesozoic (Fig. 1). The Ferretta Fault reveals a top-to-the-W normal fault geometry and forms the eastern boundary of an Eo-/Oligocene half-graben. The throw of this fault varies along strike, ranging from approximately $0.1 \mathrm{~s} \mathrm{TWT}$ in the south to approximately $0.3 \mathrm{~s}$ TWT along its central parts, corresponding to values in the order of $170-500 \mathrm{~m}$. Further to the north its throw diminishes again, suggesting a northward termination of the Ferrette Fault outside of the area mapped. Interestingly, the greatest throw is measured in the area of the along-strike prolongation of the ENEoriented Florimont and Réchésy flexures (eastern part of profile BB' indicated in Fig. 4).

West and east of the Ferrette Fault, additional NNEtrending normal faults were mapped, the most important of which is the Illfurth Fault, delimiting the DM to the east (Fig. 1). Interestingly, the throw of this fault progressively diminishes southwards, until it becomes insignificant along an ENE-oriented zone paralleling the en-échelon aligned flexures (Fig. 4).

The most important of the ENE-trending faults (Permo-Carboniferous set) is located beneath the Flor-
Fig. 4 Structural map of the base-Mesozoic surface in $\mathrm{s}$ TWT and dissecting faults. The reference datum is at $500 \mathrm{~m}$ above sea level. Numbers on map margin refer to Swiss National coordinates. Top right inset: distribution of Eo-/Oligocene conglomerates along the en-échelon flexures

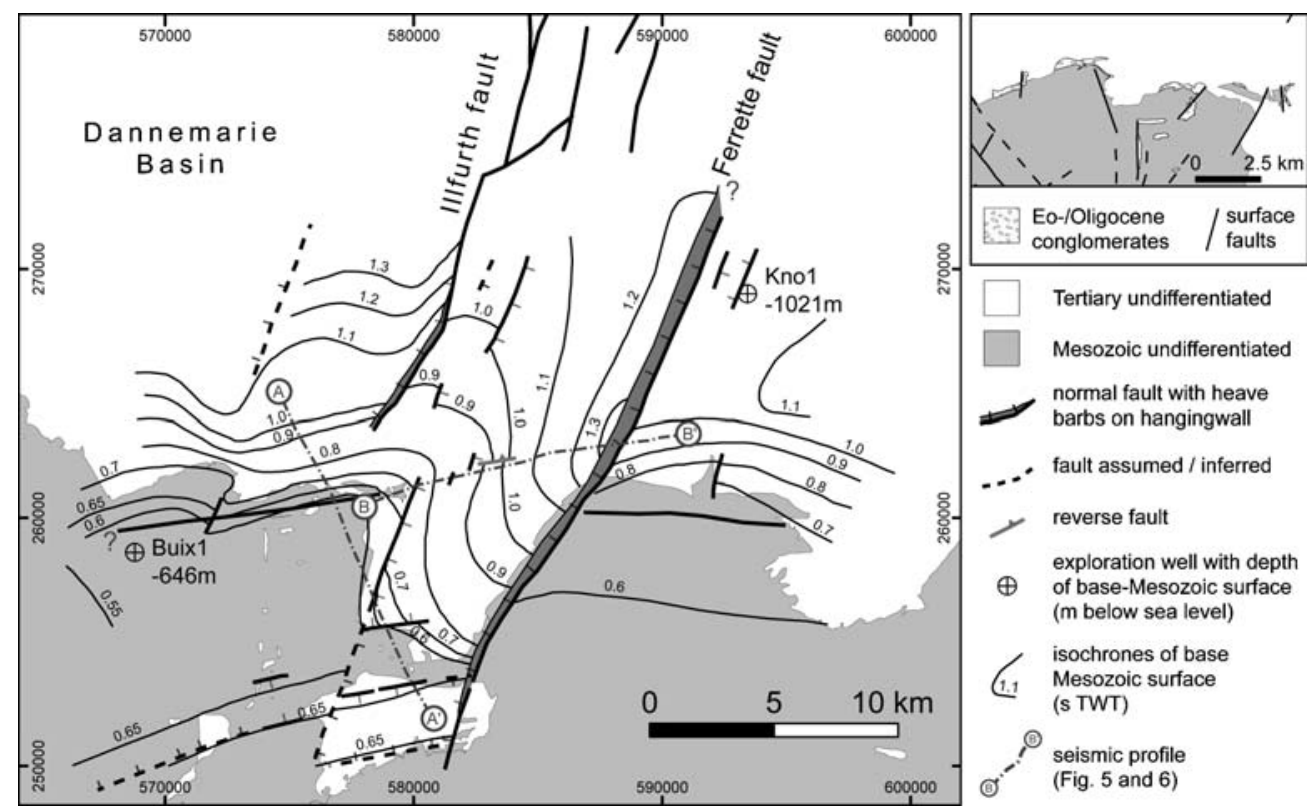


imont and Réchésy flexures (Figs. 1, 4, 5). Apart from the evidence provided by Fig. 5, its existence can be inferred from the en-échelon arrangement of the flexures, which indicates that an underlying basement fault accommodated sinistral wrench motions parallel to the RBTZ (Ustaszewski et al. 2005). Other faults, paralleling this trend, were identified further south within the autochthonous Mesozoic and along the northern and southern border of the lozenge-shaped Tertiary basin located at the southern end of profile AA' (Fig. 5). The amount of throw along the latter faults is in the order of $0.05 \mathrm{~s}$ TWT, corresponding to some $80-90 \mathrm{~m}$.

\section{Seismic sections}

Figure 5 depicts a NNW-SSE-trending, $13.5 \mathrm{~km}$ long reflection-seismic profile that crosses the Réchésy flexure (see Fig. 1), located at the southern margin of the URG (for location see Fig. 4). North of the crest of the flexure, Mesozoic strata (characterised by strictly parallel reflections) dip uniformly to the north. Upper Priabonian to Lower Rupelian syn-rift sediments onlap the top-Mesozoic unconformity and wedge out along the northern flank of the flexure. Across the flexure's crest, Mesozoic seismic reflectors are intensely disturbed. The base of the Mesozoic is vertically offset across a relatively wide basement fault zone with a top to the north normal fault component that trends approximately ENE (Fig. 4). This fault zone presumably represents a reactivated Late Palaeozoic high angle basement fault, delimiting PermoCarboniferous troughs and highs (see Fig. 2).

South of the hinge of the flexure, Mesozoic reflectors dip gently to the south. This is due to post-Late Pliocene reactivation and shortening that modified the formerly extensional flexure into a gentle anticline (Giamboni et al. 2004). Further south, in the Tabular Jura, characterised by sub-horizontal Mesozoic reflections, the seismic line runs across the southwestern end of a small Tertiary embayment. South of a gentle anticline (Vendlincourt anticline; Meyer et al. 1994), which inverts an approximately $2.5 \mathrm{~km}$ wide Mesozoic horst, Mesozoic reflectors again dip southward beneath the fill of a small intramontane Tertiary basin. The former Mesozoic horst north of this basin is bounded by ENEtrending basement faults. Again, these faults presumably formed during Permo-Carboniferous transtension, and were reactivated in extension during the Palaeogene. At the base of the Mesozoic level, their throw is in the order of ca. $0.05 \mathrm{~s}$ TWT, corresponding to some $80-90 \mathrm{~m}$.

Along the northern rim of the Florimont and Réchésy flexures, outcropping conglomerates consist exclusively of Upper Jurassic material (top right inset in Fig. 4). Sedimentological criteria indicate transport in wadi-like settings (P. Duringer, unpublished results), whereas intercalations of calcarenites suggest deposition in a coastal environment. Biostratigraphic markers within lithologically identical conglomerates further south in the Tabular Jura testify to their Upper Priabonian to Lower Rupelian age (Picot 2002; Picot et al. 2004). This indicates that the Florimont and Réchésy flexures started to form during the Upper Priabonian.

Figure 6 shows a WSW-ENE oriented reflectionseismic profile across an approximately $9 \mathrm{~km}$ wide halfgraben (for location see Fig. 4) that is bounded in the east by the west-dipping, basement-rooted Ferrette growth fault. Upper Priabonian to Lower Rupelian synrift sediments form an asymmetric wedge, which onlaps the base-Tertiary unconformity towards the west. In the immediate vicinity of the fault, an almost transparent seismic facies possibly indicates the presence of poorly sorted, Priabonian-Rupelian conglomerates (beneath the
Fig. 5 NNW-SSE-trending reflection-seismic line crossing the $\mathrm{E}-\mathrm{W}$-trending extensional Réchésy flexure at the URG-Jura boundary (data courtesy of Shell International EP). For location see Fig. 4. a un-migrated, stacked time section, $\mathbf{b}$ interpreted section
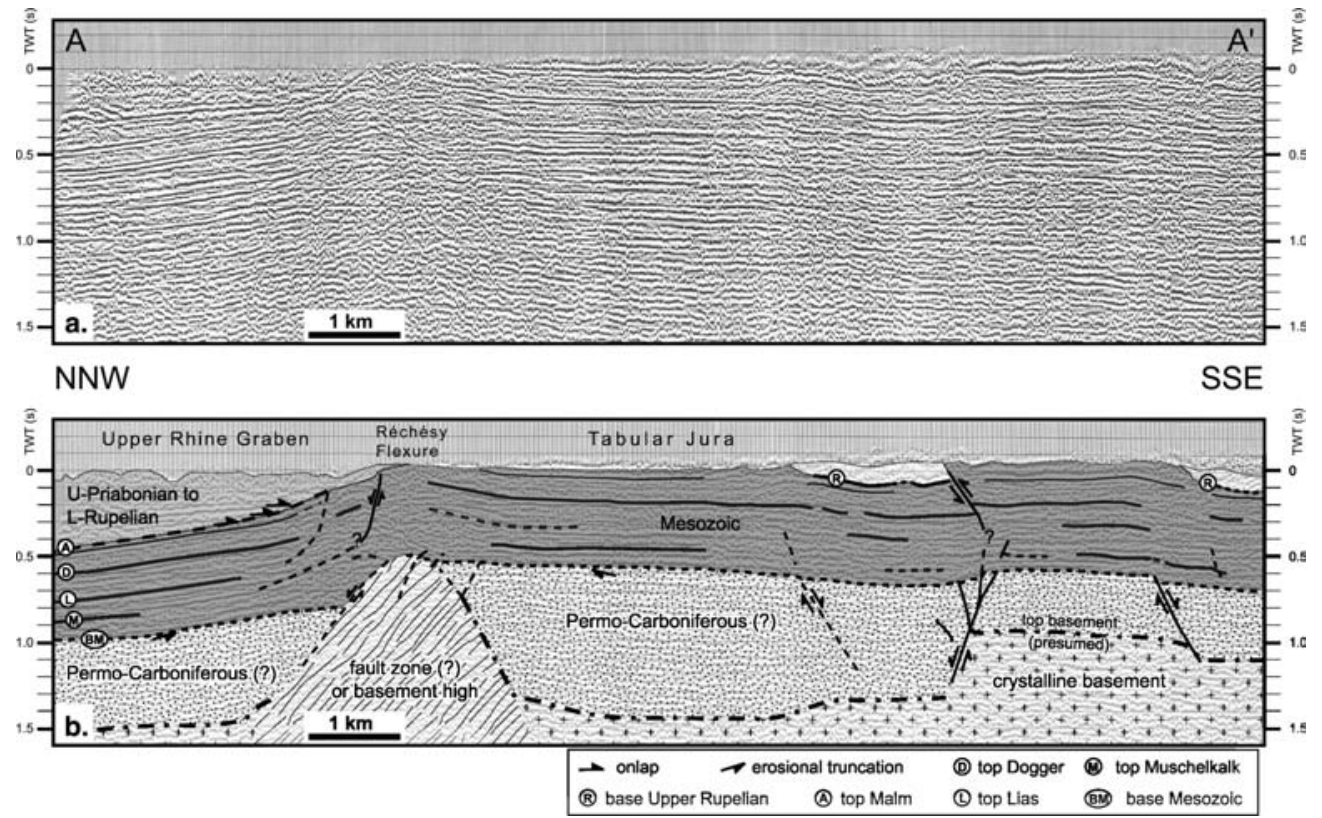
Fig. 6 WSW-ENE-trending reflection-seismic line across the NNE-trending Ferrette halfgraben bounded by URGparallel normal faults (data courtesy of Shell International EP). For location see Fig. 4. a un-migrated, stacked time section, $\mathbf{b}$ interpreted section

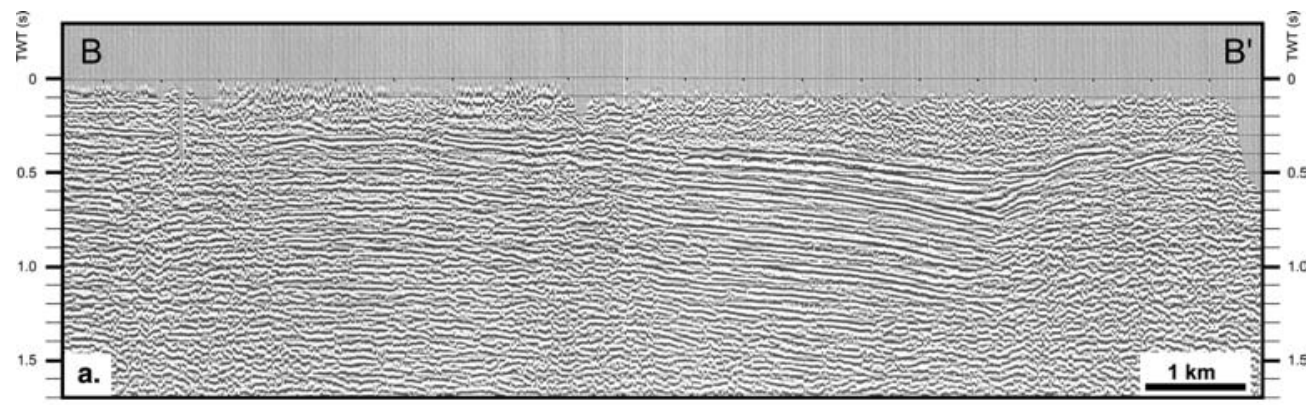

WSW

ENE

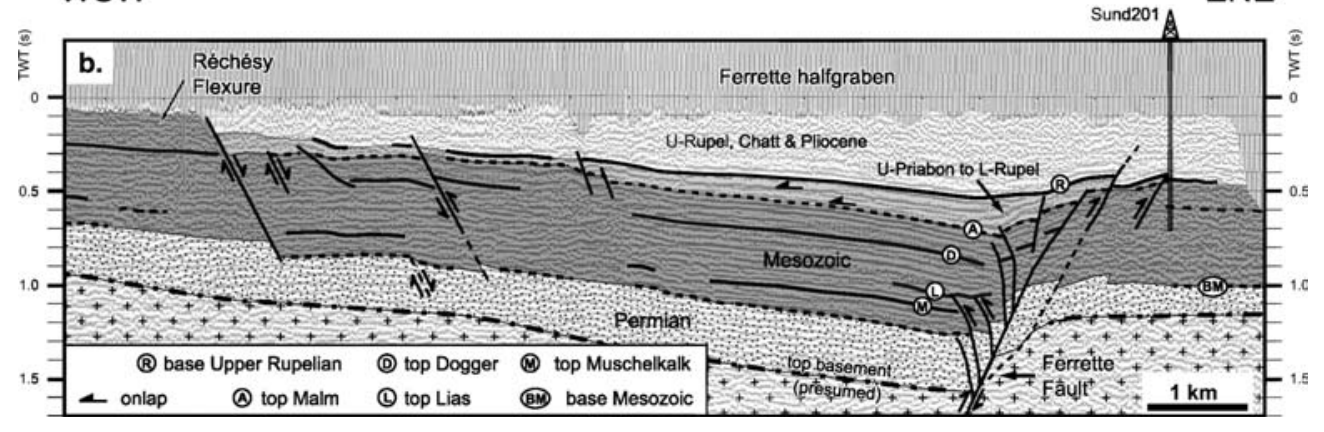

" $R$ " reflector). This is compatible with the occurrence of similar conglomerates adjacent to faults and flexures in the study area (top right inset in Fig. 4). Westward, the syn-rift sediments taper out towards an east-dipping basement fault, forming the western boundary of the half-graben and corresponding to the eastern, faultbounded termination of the Réchésy flexure.

The syn-rift-sediments contained in this half-graben consist of marly and platy "Haustein" limestones. These sediments, which were penetrated by borehole "Sund203", located some $3 \mathrm{~km}$ north of the seismic line (see Fig. 3), are of Upper Priabonian to Lower Rupelian age, as inferred from biostratigraphic data gathered in outcrops along the front of the Jura Mountains (Fischer 1965a, 1965b; Liniger 1970b; P. Duringer, unpublished results; Picot 2002; Picot et al. 2004). A pronounced reflector, corresponding to the Upper Rupelian "Meeressand" ("R" in Fig. 6, see also Fig. 3), oversteps the footwall of the Ferrette Fault where Upper Priabonian to Lower Rupelian sediments are missing. This is evidenced by borehole "Sund201" (Figs. 3, 7), which penetrated Upper Rupelian marine strata resting on Oxfordian limestones. Hence, the Upper Rupelian "Meeressand" transgression invaded areas previously unaffected by rift-related subsidence. The "Meeressand" calcarenites, which grade upwards into marine marls ("Meletta beds"), covered the domain of the autochthonous and detached Mesozoic as far south as the Delémont Basin in the Folded Jura (Fig. 1). The seismically less reflective layers above the " $R$ " reflector are attributed to Uppermost Rupelian to Chattian marine to fluvio-lacustrine sands and marls, which represent the youngest syn-rift sediments preserved in the area. These are covered by weakly reflective Late Pliocene fluvial gravels and subordinate Quaternary Loess.
The throw along the westward dipping Ferrette growth fault approaches $0.3 \mathrm{~s}$ TWT, corresponding to almost $500 \mathrm{~m}$. The presence of a half-graben normally implies a listric geometry of the controlling fault. However, evidence for listricity of the Ferrette Fault can hardly be detected on the seismic section (Fig. 6). This suggests a detachment at deeper levels, i.e. within the crystalline basement, conceivably at its brittle-ductile transition (compare Laubscher and Noack 1997). Similar half-graben structures, bounded to the east by westward dipping normal faults, have been described in the southeastern corner of the URG (see cross sections 8 and 9 in Gürler et al. 1987) and were studied in outcrops of the Folded Jura south of Basel (Laubscher 1998).

The west-dipping Ferrette Fault was reactivated under compression (or transpression), as evidenced by two top-to-the-E reverse offsets of the " $R$ " reflector to the west of borehole Sund201. The vertical offset across the more prominent western reverse fault amounts to some $0.05 \mathrm{~s}$, i.e. $<100 \mathrm{~m}$. This fault reactivation presumably occurred during the Aquitanian (Laubscher 1992).

\section{Well log interpretation}

Figure 7 gives simplified stratigraphic columns for three exploration wells located within the Ferrette half-graben, on the Ferrette horst and on the eastern flank of the half-graben, respectively (see also Fig. 3). For all three wells, the base of Upper Rupelian strata was chosen as a reference horizon. In the basinal wells Sund203 and Kno1, the Tertiary syn-rift sedimentation starts with Upper Priabonian to Lower Rupelian marly "Haustein" limestones, whereas the Ferrette block (well Sund201) was only overstepped during the Upper Rupelian 
Fig. 7 Correlation of three exploration wells with the base of Upper Rupelian sediments (shaded dark grey) as a common reference horizon. See text for discussion. Bottom right inset: base-Mesozoic structure with well locations

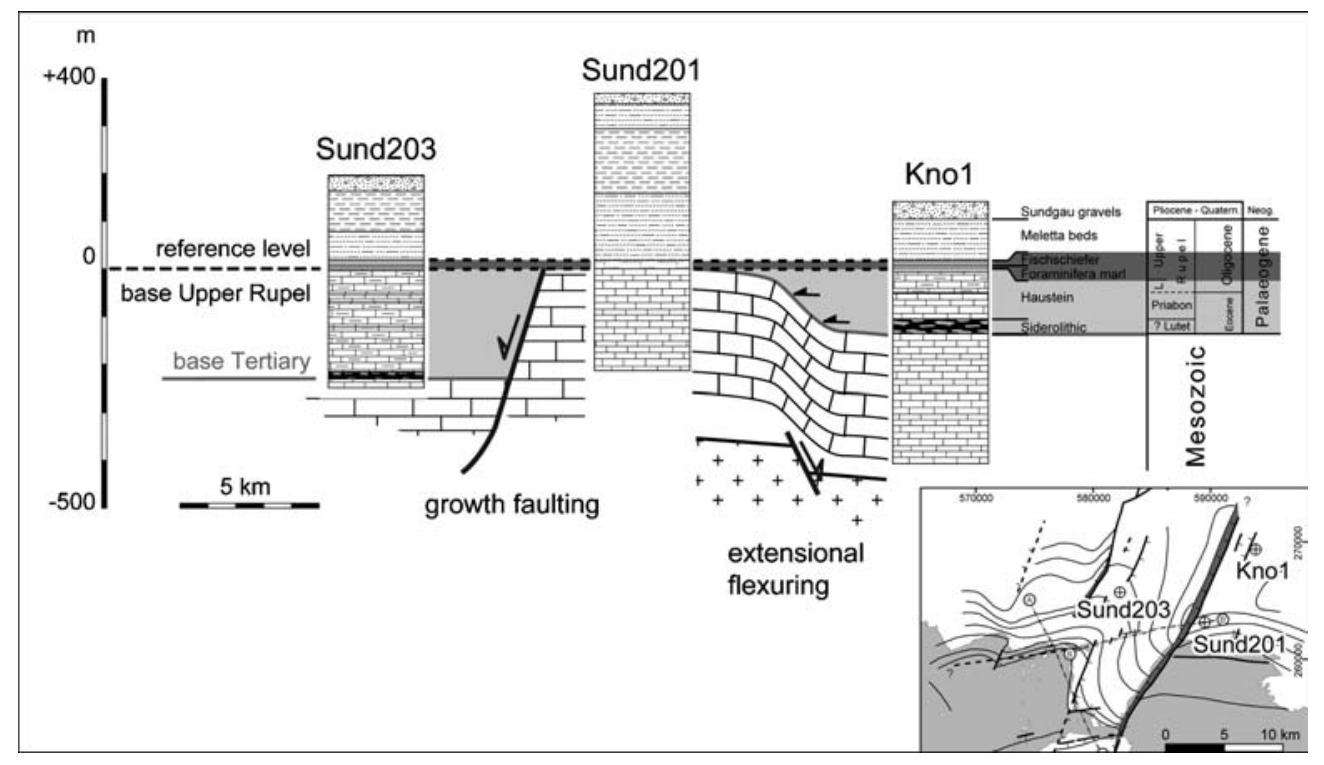

transgression. The thickness of this Upper Rupelian transgressive interval is in the order of $20 \mathrm{~m}$ in all three wells. Whereas subsidence of the Ferrette half-graben (around well Sund203 in Fig. 7) was clearly controlled by activity along the Ferrette Fault (Figs. 4, 6), which breaks through the Mesozoic series, the simultaneous subsidence of the depocenter to the NE of it (around well Knol in Fig. 7) was controlled by extensional flexuring along ENE-striking basement faults that parallel the Permo-Carboniferous faults. The sedimentary record of these three exploration wells thus shows that Upper Eocene to Lower Oligocene growth faulting along the Rhenish fault set and flexuring along the Permo-Carboniferous fault set occurred simultaneously. In order to elucidate the stress field responsible for this fault interaction, a kinematic analysis of surface faults was performed.

\section{Kinematics of rifting inferred from fault-slip data}

Fault-slip data collection

The orientations of faults and their slickensides were measured at numerous sites in the study area in order to derive the palaeostress axes orientations. A great part of the data was measured in Jurassic limestones (such as those depicted in Fig. 8) and to a lesser extent in Palaeogene syn-rift sediments (e.g. Fig. 9). Fault-slip senses were inferred from various shear sense indicators on the fault planes (Hancock 1985; Petit 1987). The most abundant indicators were slickolites, best developed in micritic Upper Jurassic limestones. Less frequently, we found slickenfibres, mainly in oolithic limestones of both Mid- and Upper Jurassic age. Crescentic (or lunate) fractures, tensile cracks and/or Riedel shear planes were restricted to massive, coralliferous Oxfordian limestones and/or to cataclasites near to or directly within fault zones. In the case of unstriated fault planes (especially in Palaeogene syn-rift sediments), the shear sense was inferred from conjugate fault geometry or from displaced markers. The quality of slip sense indicators was classified as excellent, good or poor in order to allow for weighting during subsequent palaeostress axes calculations. Additionally, the "importance" of faults was estimated in a qualitative manner based on (1) the dimensions of the exposed part of the fault plane, (2) the amount of displacement (if detectable) and (3) the presence or absence of cataclasite or fault gouge.

Overprinting relationships (superimposed slickensides, cross-cutting faults, Fig. 8) allowed the establishment of a relative chronology of faulting. This, in turn, permitted a separation of heterogeneous fault populations into homogeneous subsets that reflect one particular deformation phase only. Where field evidence and regional geologic context indicated that tilting had occurred due to post-Palaeogene folding, the fault-slip sets were rotated into a position where bedding was horizontal, before performing stress axes calculations (Fig. 10). In this study, we focus on the fault kinematics of rift-related extension of the URG only. Correspondingly, the fault sets described in the following section represent already separated, homogeneous subsets.

Analysis of fault-slip data

Twenty-eight locations in the study area yielded a sufficient number of faults per site (6 or more) to derive palaeostress axes orientations. $92 \%$ of the measured fault striations reveal pitch angles (i.e. the angle between the lineation and the horizontal, measured in the inclined fault plane) of $60^{\circ}$ or more (Fig. 11). Hence, the majority of the faults are classified as nearly ideal dipslip normal faults, whereas strike-slip faults are absent. The orientations of the maximum, intermediate and 


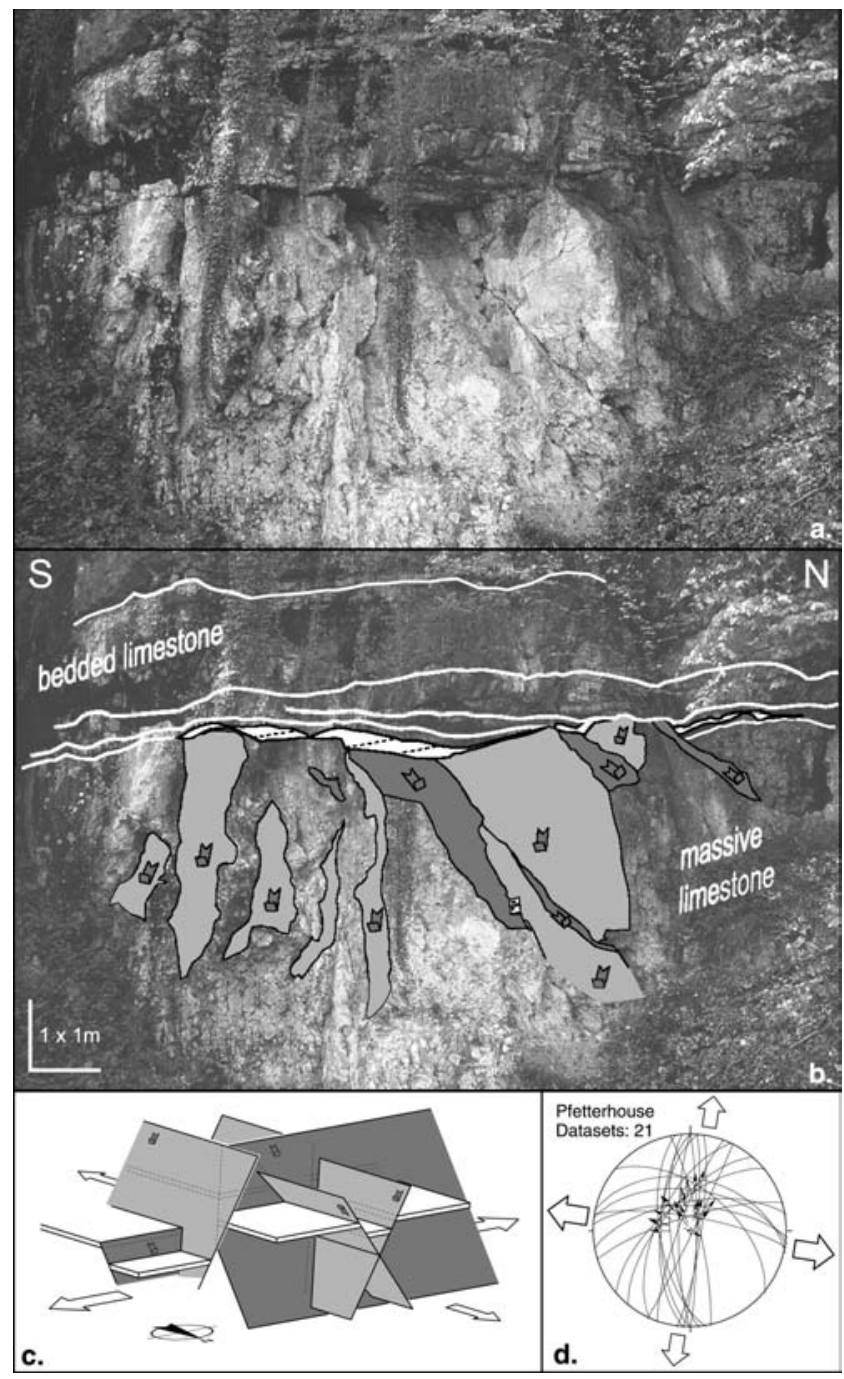

Fig. 8 a Intersecting normal faults in an outcrop of Oxfordian limestones at the eastern termination of the Réchésy flexure. bInterpreted line drawing of (a). E-W-striking fault planes (darker shading) intersect with $\mathrm{N}-\mathrm{S}$-trending faults (lighter shading). Both sets of normal faults are offset along a sub-horizontal bedding plane (white) with striations developed during Late Neogene shortening of the flexure. c Illustration of two intersecting, mutually orthogonal fault sets resulting in extension into two perpendicular directions. A marker bed is shown in white. d Fault planes from a shown in the stereographic projection (equal area, lower hemisphere). Small arrows indicate movement of the hanging-wall block. Large arrows indicate inferred extension directions

minimum principal stress axes $(\sigma 1, \sigma 2$ and $\sigma 3)$ have been determined by a variety of methods. In the case of faults lacking striations, but exhibiting a conjugate geometry and displaced markers, the principal stress axes orientations were derived as follows. The conjugate fault planes were plotted as poles. Fault planes dipping in opposite directions were separated into two subsets and the mean vectors were determined for each subset. A great circle through the mean vectors was constructed. The obtuse and acute bisectors on the great circle between the two mean vectors defined the orientations of $\sigma 1$ and $\sigma 3$, respectively (e.g. Fig. 9).
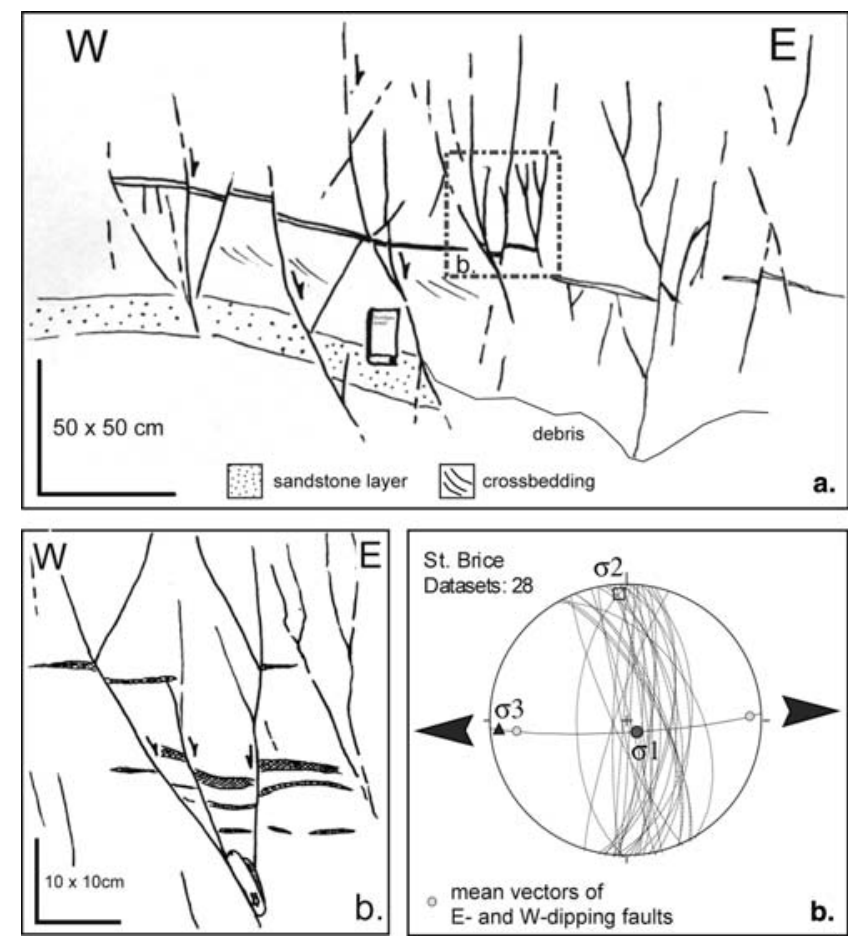

Fig. 9 a Small-scale conjugate normal faults in Chattian sands. b Detail from a with displaced markers. c great-circle representation of fault planes and derived principal stress axes. The orientation of $\sigma 1$ and $\sigma 3$ are found by bisecting the obtuse and acute angles between the poles to the mean of $\mathrm{W}$ - and E-dipping fault planes, respectively ("bisector method")

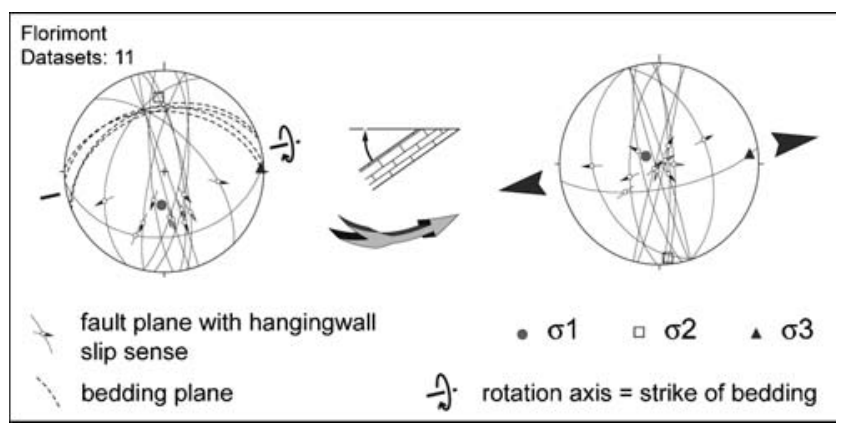

Fig. 10 Principle of back-rotating fault-slip data in order to account for tilting after fault formation. Back-rotation brings the bedding planes back into their originally horizontal position

For datasets with less than 10 fault-slip pairs, the PT-axes method was applied (Marrett and Allmendinger 1990; Peresson 1992). "TectonicsFP", the software package used for calculation and graphical output (Reiter and Acs 2000), allowed for arbitrarily choosing the angle between fault plane and the incremental shortening axis $(\mathrm{P})$. Following our observations of conjugate normal faults, which enclose an angle of ca. $60^{\circ}$ (Fig. 9), we chose an angle of $30^{\circ}$ throughout. Assuming coaxial deformation, the principal stresses $\sigma 1, \sigma 2$ and $\sigma 3$ of a given dataset coincide with the mean orientations of the $\mathrm{P}-, \mathrm{B}-$ and T-axes, respectively. 


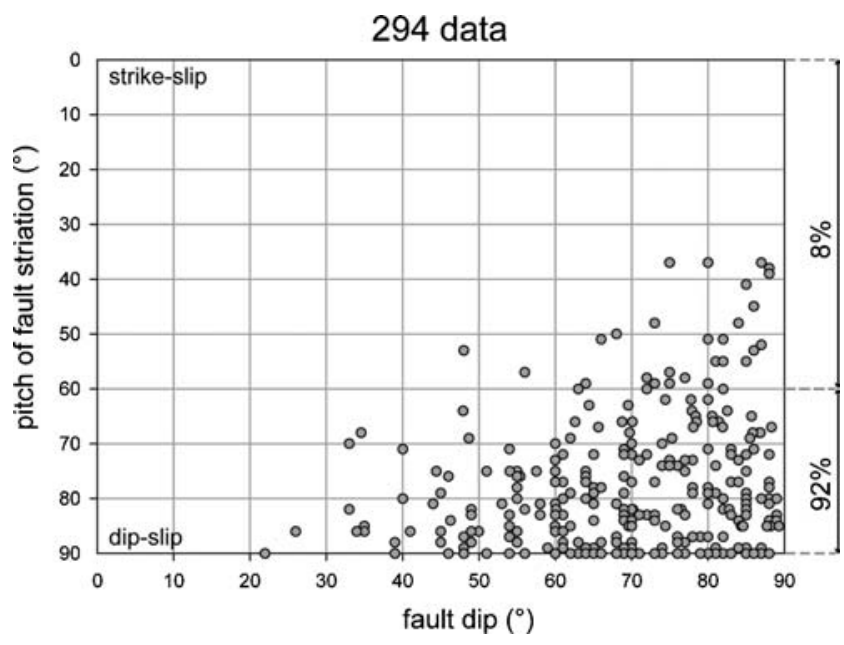

Fig. 11 Plot of fault striation pitch versus fault dip for the collected fault-slip sets. For discussion see text

Given a minimum of 10 fault-slip pairs per dataset, palaeostress tensors were calculated, yielding the principal stress axes orientations and the ratio $R=(\sigma 2-\sigma 3) /$ $(\sigma 1-\sigma 3)$, with $\sigma 1 \geq \sigma 2 \geq \sigma 3$ and $0 \leq R \leq 1$. The tensors were obtained using (1) the numerical dynamic analysis or NDA (Spang 1972; Sperner and Ratschbacher 1994) and (2) the direct inversion technique (Angelier and Goguel 1979; Angelier 1984; Angelier 1989). For each tensor we also calculated the average misfit angle $\alpha$, which is the deviation between the calculated slip lineation and the measured lineation for each fault-slip pair. The angle $\alpha$ allows one to estimate the quality of the computed stress tensors. Tensors with average misfit angles greater than $15^{\circ}$ were considered unreliable and were thus rejected. In addition, the tensor quality rank (TQR) was calculated (Delvaux et al. 1997) and allowed a classification of stress tensors into good (TQR $\geq 1.5$ ) and medium quality $(0.5 \leq \mathrm{TQR}<1.5)$.

The orientations of the principal stress axes, the distribution of $\mathrm{P}$ - and T-axes, as well as the $R$-values were considered for inferring the tectonic regime. We distinguished between (1) plane strain extension (or extension for short; $\sigma 1$ vertical, $\sigma 3$ horizontal; well defined clusters of both P- and T-axes; $\sigma 1>\sigma 2>\sigma 3 ; 0.25<R<0.75$; no deformation in $\sigma 2$-direction) and (2) radial extension $(\sigma 1$ vertical, $\sigma 3$ horizontal but poorly defined; well defined cluster of P-axes, great-circle distribution of Taxes; $\sigma 1>\sigma 2 \approx \sigma 3 ; 0<R<0.25$ ). Given the generally observed gentle plunge of $\sigma 3$, the extension direction was solely defined as the azimuth of $\sigma 3$.

The results of the principal stress axes determinations are summarised in Fig. 12 and Table 1. All plots in Fig. 12 are lower hemisphere, equal area projections. Faults are represented by great circles; the slip directions are shown as arrows indicating the movement directions of the hanging-wall blocks. Dashed lines represent conjugate faults without slip lineations. The corresponding principal stress axes are represented by filled circles $(\sigma 1)$, open squares $(\sigma 2)$ and filled triangles $(\sigma 3)$, respectively. The so derived $\sigma 3$ or extension directions were plotted at the corresponding sites in the form of diverging arrows in Fig. 13. Datasets from eight locations of Larroque and Laurent (1988) were also included. The frequency distribution of the extension directions reveals an ESE-WNW oriented maximum (Fig. 13, top left inset).

The principal stress axes distributions are shown in the right inset in Fig. 13. The $\sigma 1$-axes are tightly clustered in a sub-vertical orientation. Hence, a regime of pure extension is observed at all sites. The contoured $\sigma 3$ axes reveal a maximum at 280/11, which is oriented approximately perpendicular to the trend of the URG. However, the maximum of $\sigma 3$-axes is less well defined and the $\sigma 3$-axes scatter much more. Several datasets exhibit extension directions deviating up to $90^{\circ}$ from the WNW-ESE-oriented maximum. Deviating datasets are concentrated around the flexures that form the boundary between the URG and the adjacent Jura to the south. At outcrop scale, the datasets yielding these deviating extension directions comprise conjugate normal faults, which strike parallel to the trend of the flexures at map scale (e.g. datasets 8 and 11 in Fig. 12). Datasets from areas where Permo-Carboniferous and Rhenish fault sets overlap, reveal normal faults with highly variable strike offsetting each other (Fig. 8 and datasets 2, 12, 16 and 18 in Fig. 12). This suggests simultaneous Tertiary-age activity along both PermoCarboniferous and Rhenish fault sets.

Reduced stress tensors were calculated for 15 datasets (Table 1). The R-values obtained range between 0.48 and 0.05 , i.e. between plane strain extension and radial extension. All datasets revealing radial extension are located either directly on flexures, at intersections between Rhenish and Permo-Carboniferous faults or at intersections between Rhenish and Hercynic faults (datasets 25 and 28 in Fig. 12). At these localities, $\sigma 3$ continuously switched directions, permitting normal faulting parallel to two directions at high angles to each other.

Two structural domains, outlined in the vicinity of the roughly $\mathrm{E}-\mathrm{W}$-trending flexures delimiting the $\mathrm{URG}$ to the south (dashed boxes in Fig. 13), are of particular interest. Domain A encompasses the two en-échelon aligned Florimont and Réchésy flexures (Fig. 1) that remained largely unaffected by compression, apart from slight $\mathrm{N}-\mathrm{S}$ shortening in post-Late Pliocene times (Giamboni et al. 2004). Domain B covers the eastern part of the frontal Ferrette fold, which formed during Upper Miocene to Lower Pliocene thin-skinned Jura folding and where Neogene shortening is moderate (Fischer 1965a, b). The P- and T-axes from the 9 and 3 fault-slip sets collected in domains A and B, respectively, are shown in Fig. 14. P-axes cluster in a vertical orientation, whereas T-axes are subhorizontal and radially distributed. This is typical of radial extension.

In summary, the analysis of fault sets indicates that away from the flexures forming the boundary between 
Fig. 12 Stereographic representation of fault sets and palaeostress orientations obtained at 28 sites (equal area, lower hemisphere projections). Numbers at the lower right of each plot correspond to the numbering of the datasets in Table 1
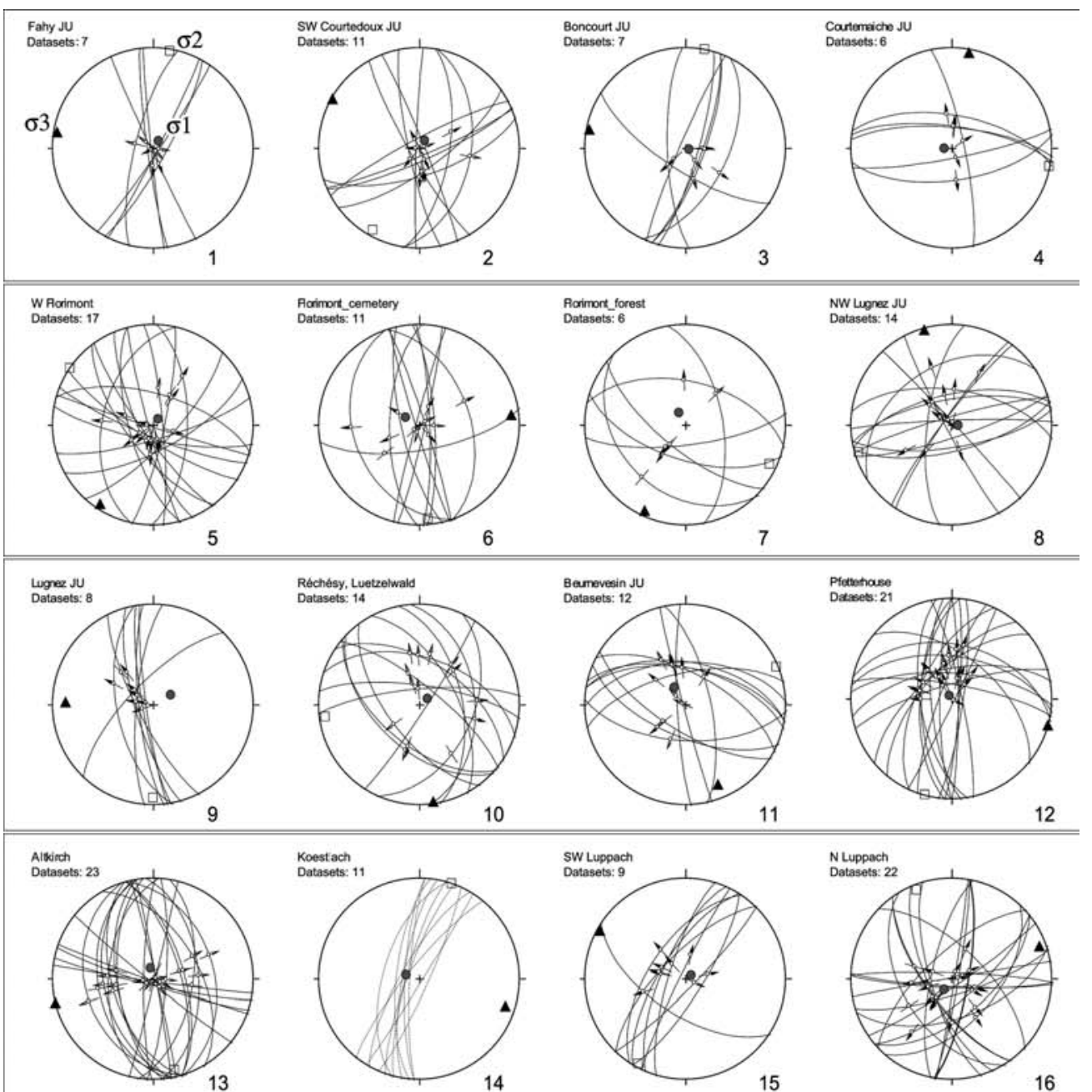

Koestach
Datasets: 11

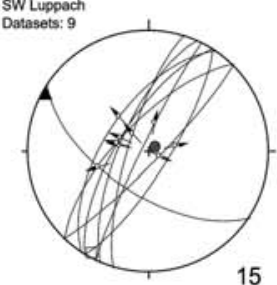

N Luppach

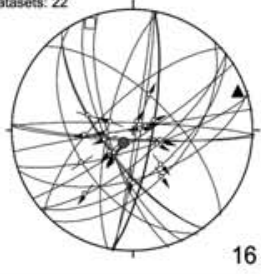

16

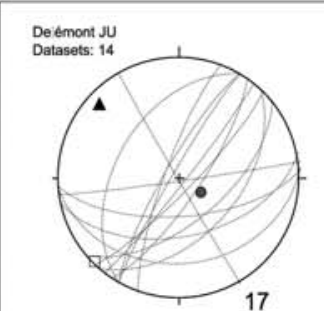

Otinguve
Datasets 11

St Brice SO
Datasets: 28

15

Leymen
Datasets: 17
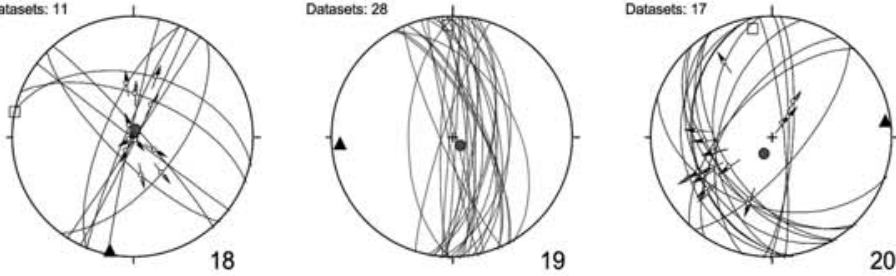

20
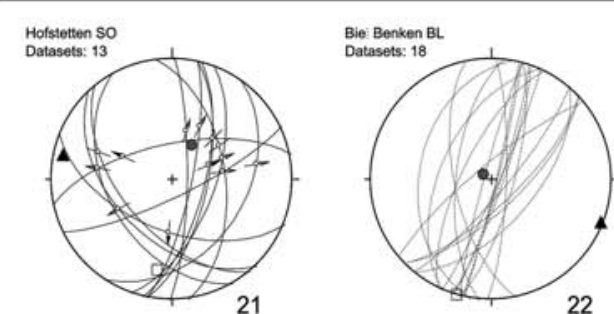

Istein

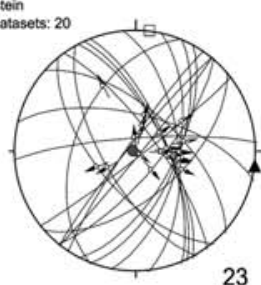

Aasch BL
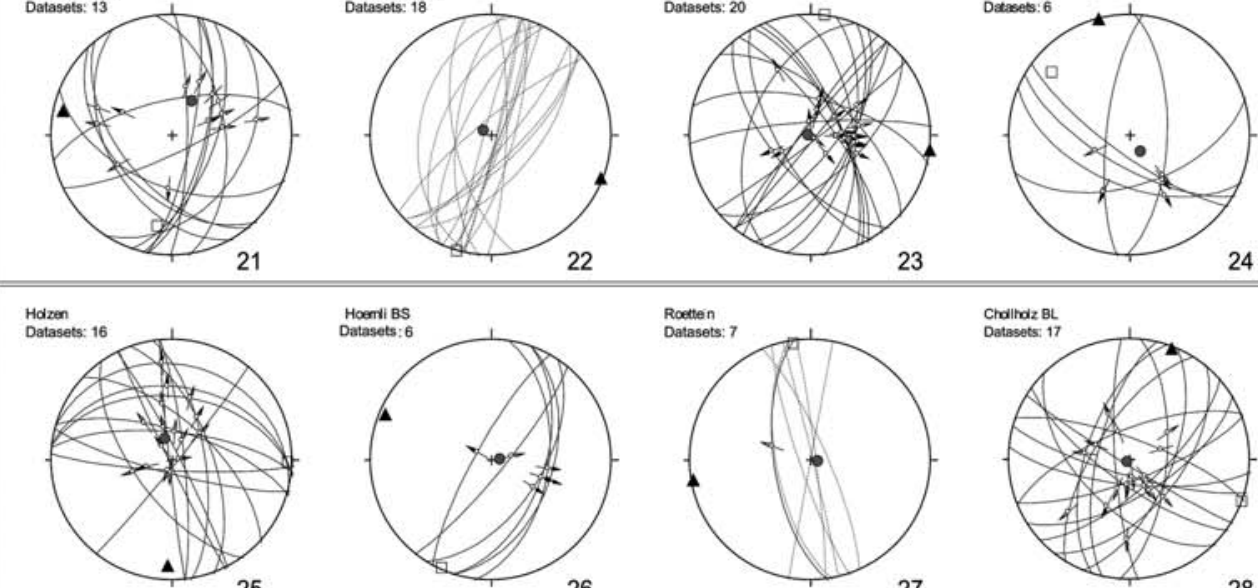

25

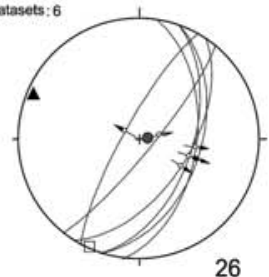

Roethen
Datasets: 7

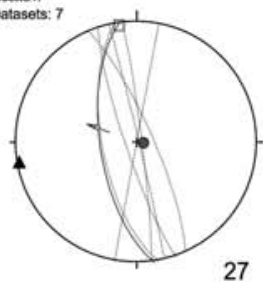

Challhoiz BL

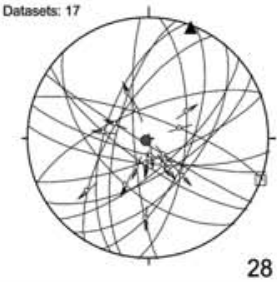




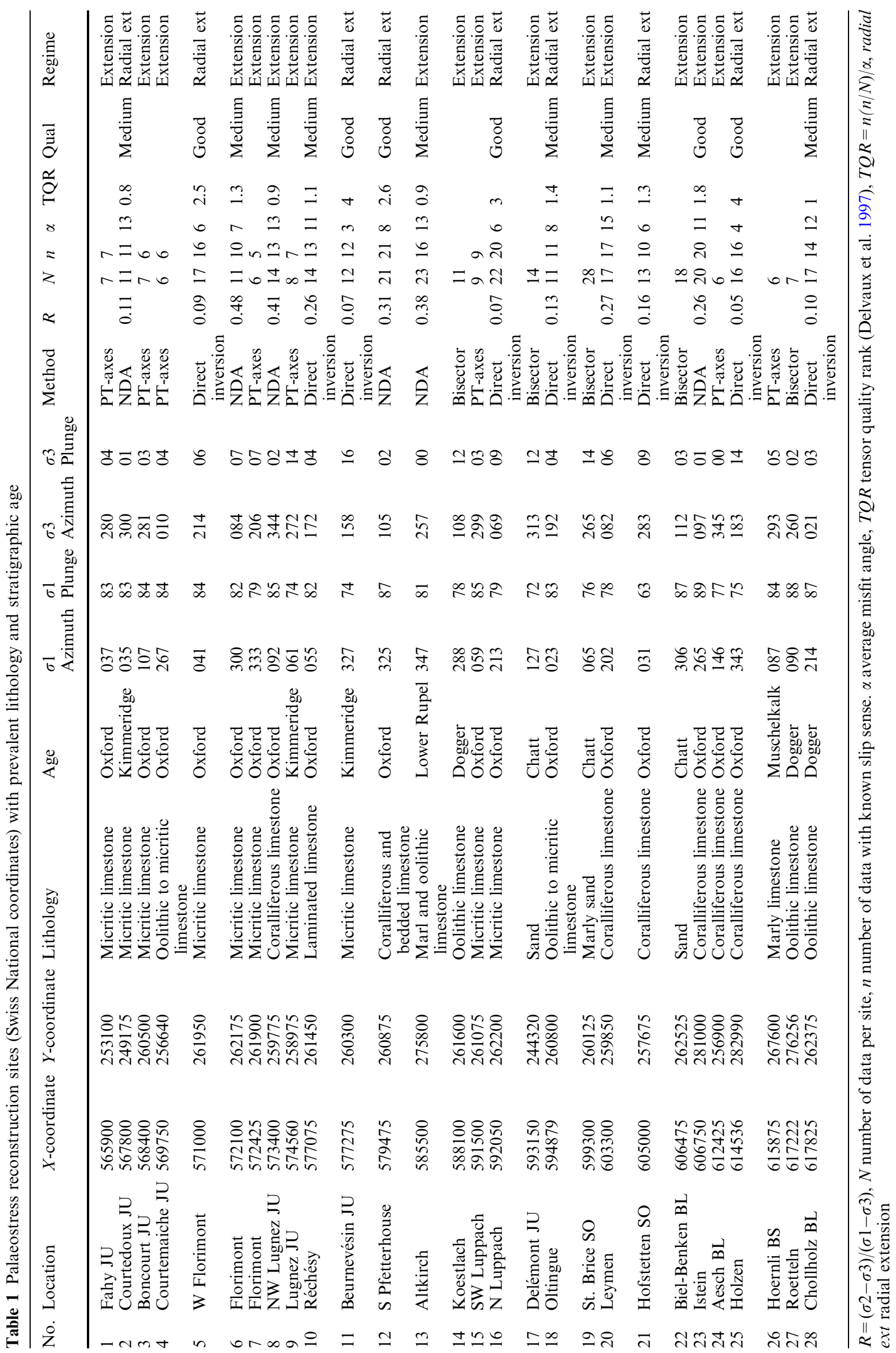


Fig. 13 Extension directions (diverging arrows) during Eo-/Oligocene rifting in the southernmost URG and adjacent Jura Mountains. Range of the figure and patterns are identical to Fig. 1. Numbers next to each arrow correspond to the numbering of the datasets in Table 1. Upper left inset: frequency distribution of extension directions obtained at 36 locations (28 locations from this study and 8 locations from Larroque and Laurent 1988). Interval width is $10^{\circ}$. Inset on right: distribution of $\sigma 1$ - and $\sigma 3$-axes for the 28 sites collected in this study (top), contoured $\sigma 1$ - (middle) and o3-axes (bottom)

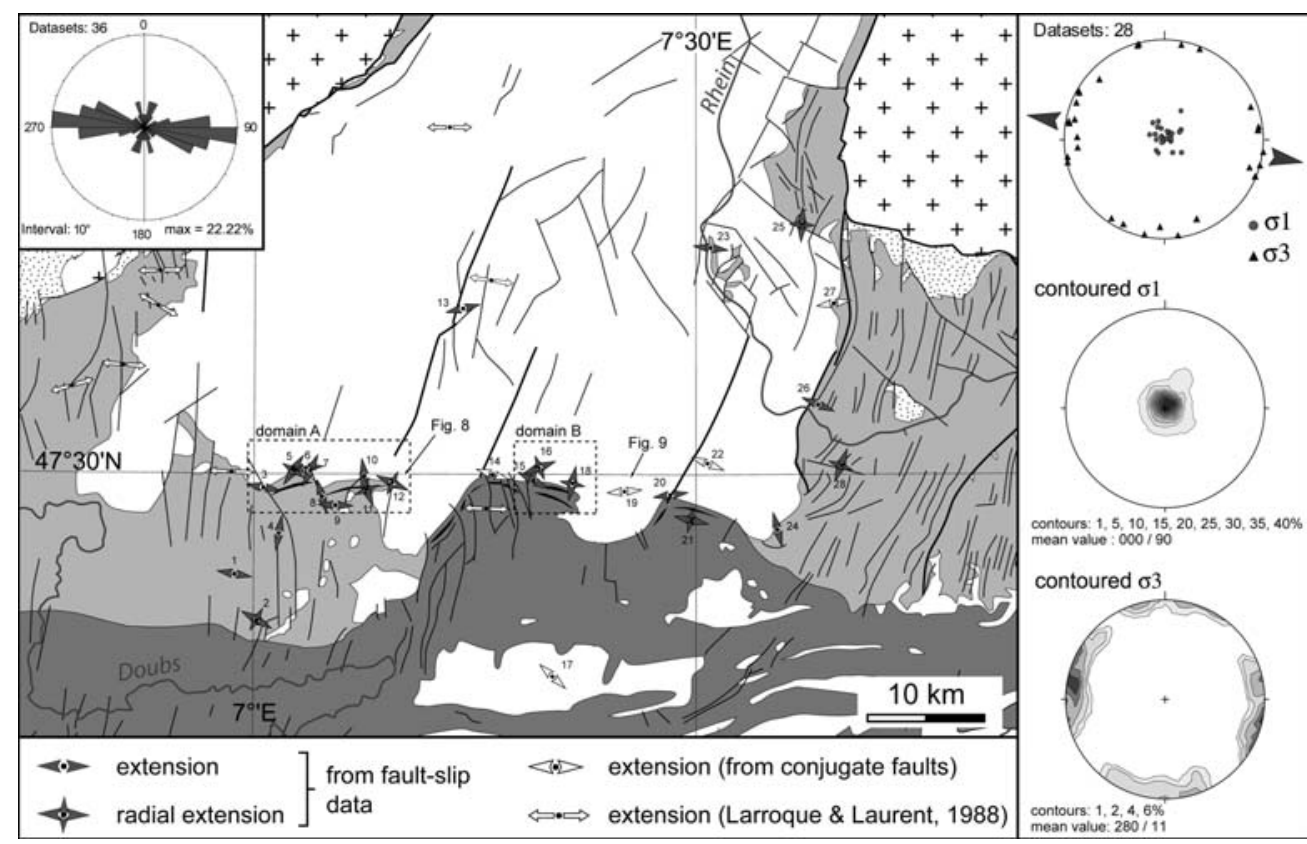

the exposed Mesozoic sediments and the URG, extension was predominantly perpendicular to the graben. Along the southern border of the URG, however, there is evidence for extension along both the pre-existing, sub-perpendicular Rhenish and Permo-Carboniferous fault sets (Fig. 2). This suggests that towards the southern margin of the URG, the stress field changed locally due to interference between these two fault sets. This confirms previously reached conclusions based on subsurface data.
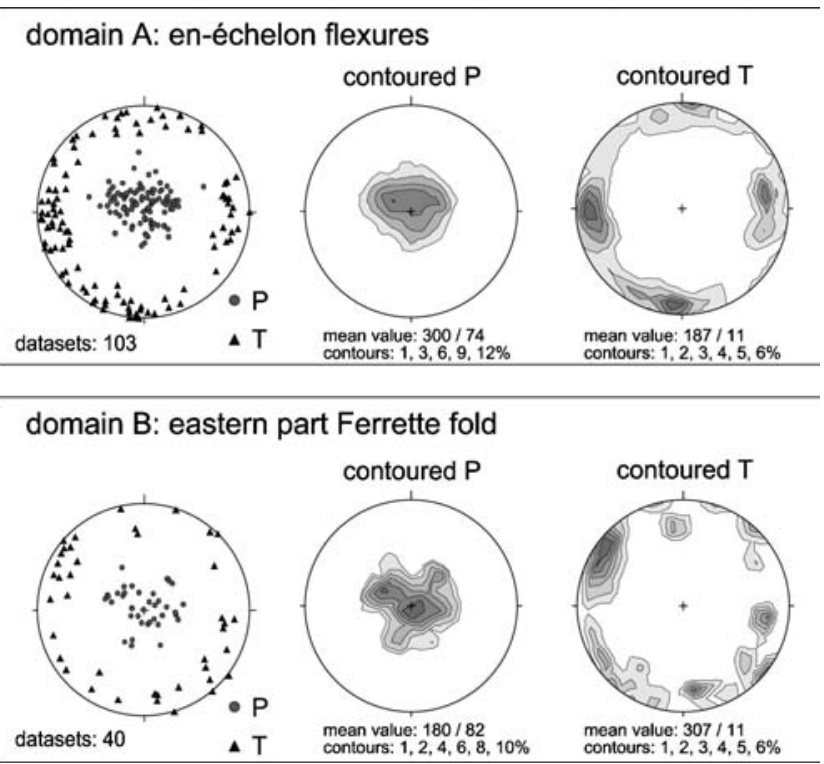

Fig. 14 Contoured P- and T-axes for faults from domains A and B (see Fig. 13 for location)

\section{Discussion and Interpretation}

The reflection-seismic and well data presented above, compiled into a base-Mesozoic structure map, show the interference of Rhenish and Permo-Carboniferous fault sets at the southern end of the URG. Half-graben structures and growth faults developed above Rhenish faults, whereas the extensional flexures were associated with Permo-Carboniferous faults. The throw on both Rhenish and Permo-Carboniferous faults was cumulative and reached values of close to $500 \mathrm{~m}$ exactly at the intersection of the two fault trends. An investigation of the stratigraphic record of wells, combined with biostratigraphic data from conglomerates associated with the faults and flexures, shows that growth faulting along Rhenish normal faults and extensional flexuring above Permo-Carboniferous basement faults were simultaneous, starting in the Upper Priabonian and lasting until the Lower Rupelian. An Upper Rupelian transgression overstepped the borders of both the extensional flexures and the half-grabens.

The kinematic analysis of outcrop-scale faults in Mesozoic pre-rift and Palaeogene syn-rift sediments, discussed in the previous chapter, reveals a predominance of WNW-ESE-oriented extension, approximately perpendicular to the trend of the southern URG. The extension affected sediments as young as Chattian, and is consequently attributed to Eo-/Oligocene URG rifting. This WNW-ESE-oriented extension is compatible with results obtained from other parts of the URG, the Tabular Jura (Larroque and Laurent 1988), the RBTZ (Bergerat 1987; Villemin and Bergerat 1987; Lacombe et al. 1993), as well as, on a larger scale, from the European Platform (Bergerat 1987). Consequently, the derived WNW-ESE-directed extension is considered a 
regional trend. However, we observe that this WNWESE-oriented, regional extension is superimposed with simultaneous $\mathrm{N}-\mathrm{S}$-oriented extension along the southern end of the URG, which leads locally to radial extension. This radial extension is found predominantly in the vicinity of the extensional flexures delimiting the URG to the south and in areas where Rhenish and PermoCarboniferous, or subordinately Rhenish and Hercynic fault sets overlap. In these cases, extension occurred simultaneously in strongly varying directions. The radial extension is illustrated by the distribution of P- and Taxes and the R-values of the reduced stress tensors.

In the vicinity of the flexures at the southern end of the URG, extension directions deviating from the regional WNW-orientation are at high angles or even perpendicular to the strike of the flexures. These deviating extension directions are most probably due to stretching of the limestone-dominated sediments in the outer arc of the flexured Mesozoic cover. Such arcing or flexuring of the sediments above the steeply dipping topto-the- $\mathrm{N}$ basement fault was facilitated by decoupling along mechanically weak layers, such as the up to $100 \mathrm{~m}$ thick halite and anhydrite intercalations in the Mid-and Upper Triassic, penetrated by well Buix1 (Fig. 3). Additionally, the local stress field was influenced by the interaction of Rhenish and Permo-Carboniferous faults (and subordinately also by interference between Rhenish and Hercynic fault sets). In summary, we propose that the orientation of pre-existing structures and the interaction between these different fault sets caused the observed stress field changes along the southern border of the URG.

The Permo-Carboniferous faults trend at angles between $20^{\circ}$ and $25^{\circ}$ to the inferred extension direction (WNW-ESE) derived at localities away from the flexures. Combined with the observed en-échelon alignment of the Florimont and Réchésy flexures, this suggests that the reactivated underlying ENE-oriented Permo-Carboniferous basement fault also accommodated a sinistral wrench component in addition to the top-to-the- $\mathrm{N}$ normal component. The simultaneous activity along growth faults and extensional flexures might thus reflect the transition from rift-perpendicular extension prevailing further north in the URG to sinistral transtensive movements in the RBTZ (Laubscher 1970; Bergerat and Chorowicz 1981; Illies 1981; Lacombe et al. 1993).

However, it remains uncertain, where exactly and how the sinistral wrench movements inferred for PermoCarboniferous faults, accounting for some $5-7 \mathrm{~km}$ of extension across the URG (Lacombe et al. 1993), was transmitted to the brittle sedimentary cover of the RBTZ. Strike-slip faults (or faults with a pronounced oblique-slip component) are conspicuously absent in the sedimentary cover of the investigated area (Fig. 10) and apparently also elsewhere in the region (Larroque and Laurent 1988; Lacombe et al. 1993). One explanation for the absence of strike-slip faults in the cover is that the strike-slip component along the ENE-trending basement faults was partitioned between basement and sedimentary cover along a Mid- and/or Upper Triassic detachment (such as inferred for the Florimont and Réchésy flexures) and led to en-échelon extension in the cover. In addition, the total amount of sinistral strike-slip motion might have been dissipated by flexuring of the detached Mesozoic cover across several pre-existing Permo-Carboniferous faults.

The geometric relationship between extensional growth faulting, flexuring and syn-rift sedimentation at the end of the Lower Rupelian is summarised in a block diagram, given in Fig. 15. This block diagram covers part of the area for which the base Mesozoic structure map of Fig. 4 was constructed. The NNE-trending
Fig. 15 Block diagram illustrating the simultaneous development of half-grabens and extensional flexures under regional WNW-oriented extension during the Upper Priabonian to Lower Rupelian. Approximately three times vertical exaggeration. For discussion, see text. The Illfurth Fault has been omitted. Positions of seismic cross sections (Figs. 5, 6) and of Fig. 8 are indicated. Bottom inset shows extent of block model on map in Fig. 4 (dashed rectangle)

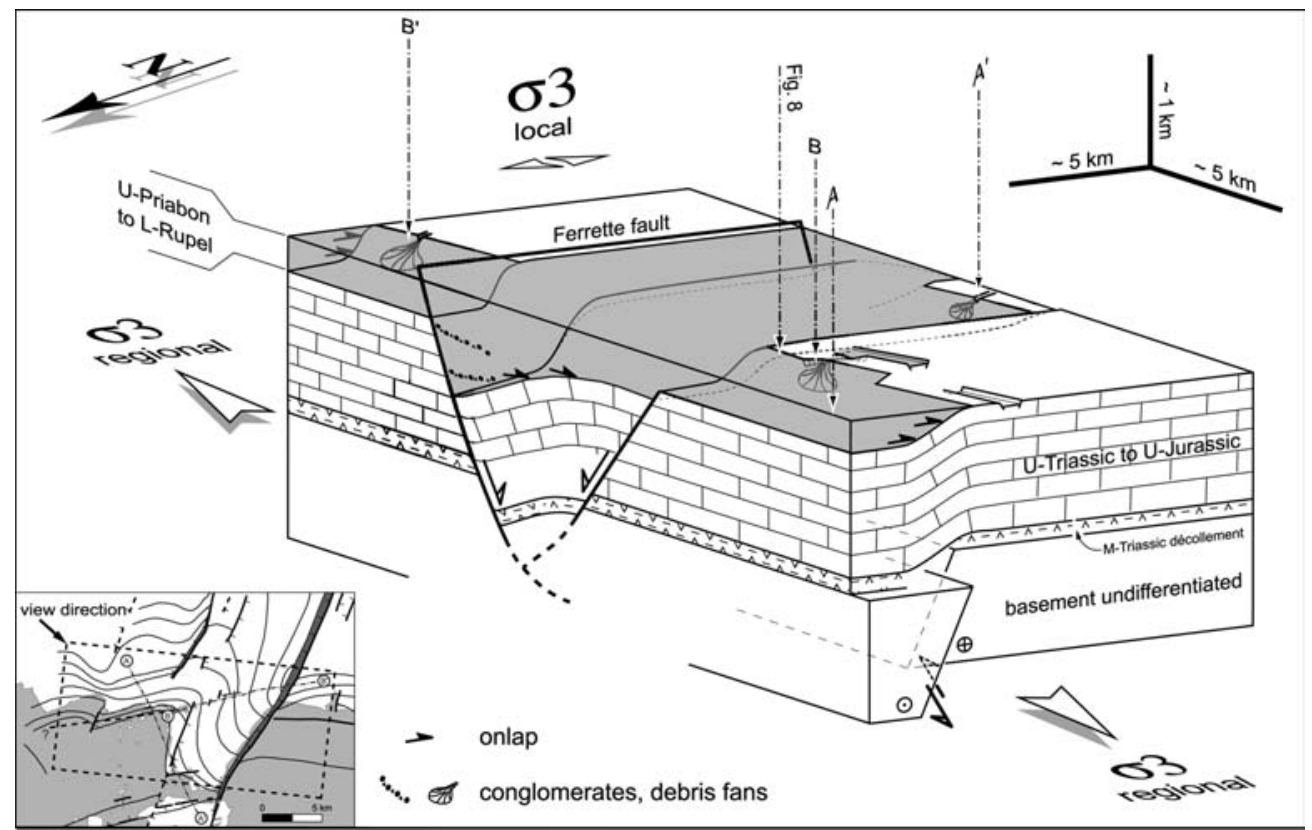


Ferrette Fault bounds the east-dipping Ferrette halfgraben. A smaller normal fault, antithetic with respect to the Ferrette Fault, bounds the half-graben in the west. The half-graben geometry implies a listric configuration of the Ferrette Fault with a detachment level presumably rooted at the crustal brittle-ductile transition. En-échelon aligned flexures are developed above an ENE-oriented high-angle basement fault, which reveals sinistral strike-slip kinematics with a pronounced oblique-slip component. Decoupling across Middle Triassic evaporites allowed extensional flexuring of the overlying Mesozoic strata. Extensional growth faulting and flexuring occurred under regional WNW-ESE-extension. However, extensional flexuring above reactivated Permo-Carboniferous basement faults induced local $\mathrm{N}-\mathrm{S}$-oriented extension. This led to a local superposition of both extensional directions. Simultaneous faulting and flexuring created accommodation space and relief that allowed the accumulation of onlapping syn-rift lacustrine to brackish marls and the development of debris fans in the immediate vicinity of normal faults and flexures.

\section{Conclusions}

At the southern end of the URG the NNE-trending extensional fault system interferes with the ENE-trending system of the RBTZ. Rifting initiated in Upper Priabonian times under regional WNW-ESE-extension, roughly perpendicular to the graben axis. Within the URG, NNE-striking half-grabens with hanging-wall growth faults formed. Simultaneously, ENE-trending extensional flexures evolved above reactivated PermoCarboniferous basement faults that controlled the transition from the URG to the RBTZ. The en-échelon alignment of these flexures suggests that the underlying ENE-oriented basement faults accommodated sinistral wrench movements in addition to the throw.

The interference of extensional flexuring and growth faulting resulted in cumulated throws along NNEtrending, half-graben-bounding normal faults during the Upper Priabonian to Lower Rupelian. An Upper Rupelian transgression overstepped areas previously unaffected by rifting, including the northernmost Jura as far south as the Delémont Basin.

To the north of the RBTZ, regional WNW-ESEextension is well defined along the fault system of the URG. However, along the RBTZ there is evidence for local N-S-directed extension. This deviating stress field is mostly restricted to areas located near extensional flexures. As this deviating $\mathrm{N}-\mathrm{S}$-extension trends perpendicularly to the extensional flexures, it is thought to reflect stretching of the sedimentary cover above top-tothe-N brittle basement faults. Outcropping fault-slip sets reveal simultaneous activity along NNE-trending extensional growth faults and ENE-trending extensional flexures and thus document the coexistence of $\mathrm{E}-\mathrm{W}$ and $\mathrm{N}-\mathrm{S}$ directed extensional stresses, defining a locally confined stress regime approaching radial extension.
Acknowledgements We were authorised to publish reflection seismic data by courtesy of Shell International EP. Marc Schaming (EOST Strasbourg) and Werner Leu (Minusio) assisted us in accessing this data. Marc Schaming and Yair Rotstein (EOST Strasbourg), Manfred Lutz (Freiburg) and Walter Müller (NAGRA, Wettingen) are thanked for discussions. Thorough and constructive reviews by an anonymous reviewer and particularly by Blanka Sperner (Karlsruhe) helped to improve the manuscript. James MacKenzie (Basel) is kindly thanked for correcting the English. This study is a contribution to the EUCOR-URGENT (Upper Rhine Graben Evolution and Neotectonics) project and benefited from logistic and financial support by the European Union-funded ENTEC (Environmental Tectonics) research and training network. We particularly acknowledge financial funding by Swiss grant BBW 99-0567-1 and the University of Basel ELTEM grant. Last but not least, we thank Peter Ziegler, the initiator of the EUCOR-URGENT project, for his continuing support over many years.

\section{References}

Allenbach R (2002) Synsedimentary tectonics in an epicontinental sea: a new interpretation of the Oxfordian basins of northern Switzerland. Eclog Geol Helv 94(3):265-287

Angelier J (1984) Tectonic analyses of fault slip data sets. J Geophys Res 89(B7):5835-5848

Angelier J (1989) From orientation to magnitudes in paleostress determinations using fault slip data. J Struct Geol 11(1-2):3750

Angelier J, Goguel J (1979) Sur une méthode simple de détermination des axes principaux des contraintes pour une population de failles. C R Acad Sci Paris 288:307-310

Bergerat F (1987) Stress fields in the European Platform at the time of Africa-Eurasia collision. Tectonics 6(2):99-132

Bergerat F, Chorowicz J (1981) Etude des images Landsat de la zone tranformante Rhin-Saône (France). Geol Rundsch 70(1):354-367

Bitterli-Brunner P (1988) Geologischer Führer der Region Basel, Birkhäuser, Basel, p 232

Boigk H, Schöneich H (1970) Die Tiefenlage der Permbasis im nördlichen Teil des Oberrheingrabens. In: Illies JH, Mueller S (eds) Graben problems. Proceedings of an international rift symposium held in Karlsruhe 1968, International Upper Mantle Project. E. Schweitzerbart'sche, Stuttgart, pp 4555

Boigk H, Schöneich H (1974) Perm, Trias und älterer Jura im Bereich der südlichen Mittelmeer-Mjösen-Zonen und des Rheingrabens. In: Illies JH, Fuchs K (eds) Approaches to Taphrogenesis. Proceedings of an international rift symposium held in Karlsruhe, 13-15 April 1972. E. Schweizerbart'sche, Stuttgart, pp 60-71

Buxtorf A (1901) Geologie der Umgebung von Gelterkinden im Basler Tafeljura. In: Beiträge zur Geologischen Karte der Schweiz, vol 11. Geologische Kommission der Schweizerischen Naturforschenden Gesellschaft, Bern, p 106

Debrand-Passard S, Courbouleix S (1984) Synthése Géologique du Sud-Est de la France, vol 2: Atlas comprenant 64 planches en couleurs. In: Mémoire du Bureau de recherches géologiques et miniéres, vol 126. BRGM, p 614

Delvaux D, Moeys R, Stapel G, Petit C, Levi K, Miroshnichenko A, Ruzhich V, San'kov V (1997) Paleostress reconstruction and geodynamics of the Baykal region. Tectonophysics 282(1-4):138

Dèzes P, Schmid SM, Ziegler PA (2004) Evolution of the European cenozoic rift system: interaction of the Alpine and Pyrenean orogens with their foreland lithosphere. Tectonophysics 389(12):1-33, doi:10.1016/j.tecto.2004.1006.1011

Diebold P (1989) Der Nordschweizer Permokarbon-Trog und die Steinkohlenfrage der Nordschweiz. Vierteljahrsschrift der Naturforschenden Gesellschaft in Zürich 133(1):143-174 
Diebold P, Naef H (1990) Der Nordschweizer Permokarbontrog. Nagra informiert 2:29-36

Diebold P, Noack T (1997) Late Palaeozoic troughs and Tertiary structures in the eastern Folded Jura. In: Pfiffner OA, Lehner P, Heitzmann P, Mueller S, Steck A (eds) Deep structure of the Swiss Alps. Results of NRP 20. Birkhäuser, pp 59-63

Doebl F (1970) Die tertiären und quartären Sedimente des südlichen Rheingrabens. In: Illies JH, Mueller S (eds) Graben poblems. Proceedings of an international rift symposium held in Karlsruhe 10-12 October 1968, International Upper Mantle Project. E. Schweizerbart'sche, Stuttgart, pp 56-66

Edel JB, Fluck P (1989) The upper Rhenish shield basement (Vosges, Upper Rhinegraben and Schwarzwald): main structural features deduced from magnetic, gravimetric and geological data. Tectonophysics 169:303-316

Elmohandes S-E (1981) The Central European Graben system: rifting imitated by clay modelling. Tectonophysics 73:69-78

Fischer H (1965a) Geologie des Gebietes zwischen Blauen und Pfirter Jura (SW Basel), Kümmerly \& Frey. Geographischer Verlag, Bern, p 106

Fischer H (1965b) Geologischer Atlas der Schweiz 1:25 000, Atlasblatt 49, Rodersdorf, mit Erläuterungen, Schweizerische Geologische Kommission, Bern

Fischer H (1969) Einige Bemerkungen zur "Übersichtstabelle zur Geologie der weiteren Umgebung von Basel". Regio Basilensis 10(2):234-238

Giamboni M, Ustaszewski K, Schmid SM, Schumacher ME, Wetzel A (2004) Plio-Pleistocene transpressional reactivation of Paleozoic and Paleogene structures in the Rhine-Bresse transform zone (Northern Switzerland and Eastern France). Geologische Rundschau 93:207-233, doi: 10.1007/s00531-0000300375-00532

Gürler B, Hauber L, Schwander M (1987) Die Geologie der Umgebung von Basel mit Hinweisen über die Nutzungsmöglichkeiten der Erdwärme, Beiträge zur Geologischen Karte der Schweiz, Lieferung 160 (Neue Folge), Schweizerische Geologische Kommission, Bern, p 33

Hancock PL (1985) Brittle microtectonics: principles and practice. J Struct Geol 7(3-4):437-457

Häring M (2003) Das Neueste zum Projekt Deep Heat Mining in Basel. http://www.geothermal.ch/Einstieg_d.html (accessed on 01October 2003)

Illies JH (1981) Mechanism of Graben formation. Tectonophysics 73(1-3):249-266

Koch R (1923) Geologische Beschreibung des Beckens von Laufen im Berner Jura. In: Beiträge zur Geologischen Karte der Schweiz, Neue Folge, vol 48. Schweizerische Geologische Kommission, Bern, p 61

Lacombe O, Angelier J, Byrne D, Dupin J (1993) Eocene-Oligocene tectonics and kinematics of the Rhine-Saone continental transform zone (Eastern France). Tectonics 12(4):874-888

Larroque J, Laurent P (1988) Evolution of the stress field pattern in the south of the Rhine Graben from the Eocene to the present. Tectonophysics 148:41-58

Laubscher H (1970) Grundsätzliches zur Tektonik des Rheingrabens. In: Illies JH, Mueller S (eds) Graben problems. Proceedings of an international rift symposium held in Karlsruhe 1968, International Upper Mantle Project. E. Schweitzerbart'sche, Stuttgart, pp 79-86

Laubscher H (1972) Some overall aspects of Jura dynamics. Am J Sci 272:293-304

Laubscher H (1973) Faltenjura und Rheingraben: zwei Grossstrukturen stossen zusammen. Jber u Mitt oberrh geol Ver $55: 145-158$

Laubscher H (1982) Die Südostecke des Rheingrabens - ein kinematisches und dynamisches problem. Eclog Geol Helv 75(1):101-116

Laubscher H (1986) The eastern Jura: relations between thinskinned and basement tectonics, local and regional. Geol Rundsch 75(3):535-553

Laubscher H (1987) Die tektonische Entwicklung der Nordschweiz. Eclog Geol Helv 80:287-303
Laubscher H (1992) Jura kinematics and the Molasse Basin. Eclog Geol Helv 85(3):653-675

Laubscher H (1998) Der Ostrand des Laufenbeckens und der Knoten von Grellingen: die verwickelte Begegnung von Rheingraben und Jura. Eclog Geol Helv 91:275-291

Laubscher H, Noack T (1997) The deep structure of the Basel Jura In: Pfiffner OA, Lehner P, Heitzmann P, Mueller S, Steck A (eds) Deep structure of the Swiss Alps. Results of NRP 20. Birkhäuser, pp 54-58

Liniger H (1970a) Bemerkungen zur Tektonik am Südende des Rheingrabens. In: Illies JH, Mueller S (eds) Graben problems. Proceedings of an international rift symposium held in Karlsruhe 1968, International Upper Mantle Project, 27. E. Schweitzerbart'sche, Stuttgart, pp 103-106

Liniger $H$ (1970b) Geologischer Atlas der Schweiz 1:25 000, Atlasblatt 55: Bonfol, mit Erläuterungen, Kümmerly \& Frey, Bern

Lutz M (1964) Stratigraphische und tektonische Untersuchungen am südwestlichen Schwarzwaldrand zwischen Wiesental und Hochrhein. Oberrhein geol Abh 13:75-122

Marrett R, Allmendinger RW (1990) Kinematic analysis of faultslip data. J Struct Geol 12(8):973-986

McClay K, Dooley T, Whitehouse P, Mills M (2002) 4-D evolution of rift systems: Insights from scaled physical models. AAPG Bull 86(6):935-959

Meyer B, Lacassin R, Brulhet J, Mouroux B (1994) The Basel 1356 earthquake: which fault produced it? Terra Nova 6:54-63

Peresson H (1992) Computer aided kinematic analysis of fault sets. Mitt Ges Geol Bergbaustud Österr 38:107-119

Petit JP (1987) Criteria for the sense of movement on fault surfaces in brittle rocks. J Struct Geol 9(5-6):597-608

Pfiffner OA, Erard P, Stäuble M (1997) Two cross sections through the Swiss Molasse Basin (lines E4-E6, W1, W7-W10). In Pfiffner OA, Lehner P, Heitzmann P, Mueller S, Steck A (eds) Deep structure of the Swiss Alps. Results of NRP 20. Birkhäuser, pp 64-72

Pflug R (1982) Bau und Entwicklung des Oberrheingrabens, Wissenschaftliche Buchgesellschaft Darmstadt, Darmstadt, pp 1145

Picot L (2002) Le Paléogéne des synclinaux du Jura et de la bordure sud-rhénane: paléontologie (Ostracodes), paléoécologie, biostratigraphie et paléogéographie. $\mathrm{PhD}$ Thesis, Institute of Geology and Paleontology, University of Fribourg, vol 5, p 240

Picot L, Becker D, Lapaire F, Ustaszewski K, Hug WA, Berger JP (2004) Sédimentologie, paléontologie et reconstruction des paléo-environnements côtiers de la bordure sud-rhénane (Groupe des Gompholites et Conglomérats, Paléogéne, Jura, Suisse). Eclog Geol Helv (in press)

Reiter F, Acs P (1996-2000) TectonicsFP. Computer Software for Structural Geology, version 2.0 PR. http://www.tectonicsfp.com/

Schmassmann H, Bayramgil O (1945) Stratigraphie, Petrographie und Paläogeographie der Perm-Formation im schweizerischen Tafeljura und die Steinkohlenfrage der Nordschweiz. Tätigkeitsberichte der Naturforschenden Gesellschaft Baselland 15:15-114

Schmidt C, Braun L, Paltzer G, Mühlberg M, Christ P, Jacob F (1924) Bohrungen von Buix bei Pruntrut und Allschwil bei Basel. Beiträge zur Geologie der Schweiz. Geotechnische Serie, X. Lieferung: $p 74$

Schumacher ME (2002) Upper Rhine Graben: role of preexisting structures during rift evolution. Tectonics 21(1):1006, doi:1010.1029/2001TC900022

Sissingh W (1998) Comparative Tertiary stratigraphy of the Rhine Graben, Bresse Graben and Molasse Basin: correlation of Alpine foreland events. Tectonophysics 300:249-284

Spang J (1972) Numerical method for dynamic analysis of Calcite Twin lamellae. Geol Soc Am Bull 83(2):467-472

Sperner B, Ratschbacher L (1994) A turbo Pascal program package for graphical presentation and stress analysis of calcite deformation. Z Deutsch Geol Ges 145:414-423 
Sprecher C, Müller W (1986) Geophysikalisches Untersuchungsprogramm Nordschweiz: Reflexionsseismik 82. In: Nagra Technischer Bericht NTB 84-15, NAGRA, Baden, p 168

Tron V, Brun J-P (1991) Experiments on oblique rifting in brittleductile systems. Tectonophysics 188:71-84

Ustaszewski K, Schumacher ME, Schmid SM, Nieuwland D (2005) Fault reactivation in brittle-viscous wrench systems - dynamically scaled analogue models and application to the RhineBresse Transfer Zone. Q Sci Rev (in press)

Villemin T, Bergerat F (1987) L'évolution structurale du fossé rhénan au cours du Cénozoïque: un bilan de la déformation et des effets thermiques de l'extension. Bull Soc géol France 3(2):245-255

Werner W, Franzke HJ (2001) Postvariszische bis neogene Bruchtektonik und Mineralisation im südlichen Zentralschwarzwald. Z Deutsch Geol Ges 152(2-4):405-437
Wetzel A, Allenbach R, Allia V (2003) Reactivated basement structures affecting the sedimentary facies in a tectonically "quiescent" epicontinental basin: an example from NW Switzerland. Sediment Geol 157:153-172

Ziegler PA (1990) Collision related intra-plate compression deformations in Western and Central Europe. J Geodynam 11(4):357-388

Ziegler PA (1992) European Cenozoic rift system. Tectonophysics 208:91-111

Ziegler PA, Schumacher ME, Dézes P, van Wees J-D, Cloetingh S (2004) Post-Variscan evolution of the lithosphere in the Rhine Graben area: constraints from subsidence modelling. In: Wilson M (ed) Permo-Carboniferous magmatism and rifting in Europe, vol 223. Geological Society, pp 289-317 